\title{
THE NEW KEYNESIAN PHILLIPS CURVE AND THE EFFECTS OF DOMESTIC INFLATION DRIVERS IN THE REPUBLIC OF SERBIA
}

\author{
Vladimir Mihajlovic ${ }^{*}$ \\ Faculty of Economics, University of Kragujevac, Kragujevac, The Republic of Serbia
}

\begin{abstract}
This study investigates the validity of the New Keynesian Phillips curve in the Republic of Serbia. By means of empirical analysis, the impact of domestic inflation drivers, i.e. inflation expectations, real marginal costs and the output gap, is quantified. The results reveal that inflation in Serbia responds more intensively to negative rather than positive supply and demand shocks as it decreases more significantly in economic contraction than in expansion. The estimated model of the New Keynesian Phillips curve with marginal costs gives the unambiguous evidence that the growth of cost-push inflation could be reduced by a productivity-enhancing policy. Expected inflation significantly impacts the actual inflation rate, albeit inflation dynamics are dominated by inertia, i.e. past rates affect the current. The empirical estimate of the New Keynesian Phillips curve model with the output gap that indicates monetary expansion in the Republic of Serbia might, inter alia, stimulate the economic activity without causing significant inflationary pressures to occur.
\end{abstract}

Keywords: inflation rate, output gap, unit labor costs, nonlinear ARDL model, dynamic multiplier, asymmetry

JEL Classification: B22, C13, C32, E31

\section{INTRODUCTION}

The contemporary analysis of inflation dynamics is commonly based on the New Keynesian Phillips curve (NKPC). In its original version, the curve represents the effect of domestic inflation drivers in the closed economy model. Actual inflation is determined by

* Correspondence to: V. Mihajlovic, Faculty of Economics University of Kragujevac, Liceja Knezevine Srbije 3, 34000 Kragujevac, The Republic of Serbia;

e-mail:vmihajlovic@kg.ac.rs expected future inflation and the factors of the real economic activity, such as real marginal costs and the output gap as a deviation of the actual output from the potential. Despite growing interdependence among national economies, a number of recent research studies (Globan, Arčabić \& Sorić, 2015; Hałka \& Kotłowski, 2016; Abdih, Lin \& Paret, 2018) clearly confirm the fact that inflation dynamics in developed and emerging economies are determined by domestic inflation drivers. A study of the European Central Bank indicates that global inflation drivers had a 
statistically significant impact on inflation in the Eurozone only in period from 2008 to 2009, whereas in the period from 2012 to 2015, domestic factors were dominant. In transition countries, the impact of domestic inflation drivers is specific and was commonly determined by the intensity of the reform processes towards the market economy. The relative significance of particular drivers evolves as transition progresses, so that the dominance of the output gap, the fiscal deficit and political cycles in initial phases are subsequently substituted by the impact of food and oil prices, the exchange rate regime, and the current account in mature phases (Petrović, Mladenović \& Nojković, 2011).

Compared with other countries, the Republic of Serbia started transition reforms relatively late. Initially, as in other transition economies, a high inflation rate was the corollary of these reforms. During the 2010s, due to the monetary policy regime based on inflation targeting, monetary stability was enhanced, along with inflation volatility reduction (Narodna banka Srbije, 2018). However, the dynamics of the domestic drivers (the output gap, aggregate demand, the productivity rate, inflation expectations) were characterized by large fluctuations in the mention period. Assumed by the NKPC concept, a strong association between these drivers and the inflation rate raises the issue of the validity of this curve in the context of the Republic of Serbia, as well as the exact impact of these inflation drivers.

Not disputing the effect of external factors (the exchange rate, the import/export share in the GDP, the oil price, etc.), this study tries to extract the impact of the domestic inflation drivers in the Republic of Serbia, because a better understanding of the mechanism and the extent of their influence contributes to the designing of more efficient monetary policy measures intended to maintain monetary stability. In addition to the above, the study investigates the nonlinearity of the NKPC in the economy of the Republic of Serbia. Bearing in mind the fact that this relationship assumes a certain extent of the price and wage rigidity in the short run, there is a possibility of the asymmetric (nonlinear) adjustment of the inflation rate to changes in the economy. For instance, if prices are rigid downwards, economic contraction might reduce the inflation rate to a lesser extent in the short run, compared with inflation growth due to economic expansion. By assumption, prices are flexible in the long run, as frictions in their adjustment diminish and the long-term reaction of inflation to the economic activity would be symmetric.

Accordingly, the empirical analysis of the validity of the NKPC in the economy of the Republic of Serbia and the investigation of the role of the domestic inflation drivers are the subject matter of this paper.

The research study is aimed at revealing whether the explanatory variables (the expected inflation rate, real marginal costs and the output gap) in a relationship have a significant impact on the actual inflation rate. Besides, a long-term asymmetry in the manner in which inflation reacts to changes in these variables is also examined. The presence of such asymmetry has important implications for the monetary policy, since the intensity of its measures should be in accord with how inflation responds to different phases of the business cycle.

The main motivation lies in the fact that quantifying the effects of the domestic drivers gave a more complete picture of inflation dynamics in the Republic of Serbia in the last decade. The research is also motivated by the fact that, according to the best of the author's knowledge, there have been no empirical studies of the NKPC nonlinearity in the Republic of Serbia to date, albeit this relationship has become the basis for the contemporary analysis of the inflation and stabilization policy.

In line with the defined subject matter and aim of the research study, the following research hypotheses are tested:

H1: The expected future inflation rate has a statistically significant impact on the actual inflation rate dynamics in the Republic of Serbia.

H2: Real marginal costs have a positive, statistically significant and symmetric long-term effect on the inflation rate in the Republic of Serbia. 
H3: The output gap changes in expansionary and contractionary periods are in a positive, statistically significant and symmetric longterm association with the inflation rate in the Republic of Serbia.

As an econometric approach suitable for testing research hypotheses, the Nonlinear Autoregressive Distributive Lag (NARDL) method developed by Y. Shin, B. Yu and M. Grenwood-Nimmo (2014) is employed. This approach allows for a joint analysis of short- and long-term relationships between dependent and explanatory variables and their asymmetric effects. In addition, it enables the presentation of the cumulative intertemporal effects of inflation drivers, as well as adjustment after the initial shock towards a long-term equilibrium (Shin et al, 2014). Furthermore, in the context of the research hypotheses, this approach helps investigate not only the direction and statistical significance of the relationships between real marginal costs, the output gap and the inflation rate in the Republic of Serbia, but also the presence of long-term asymmetry in the reaction of inflation to these drivers in expansionary and contractionary periods.

Apart from the Introduction and the Conclusion, the paper consists of the three sections: in the second section, the NKPC theoretical background is discussed and an overview of the reference empirical research studies is given; in the third section, the econometric approach and the data are presented. The results and a discussion on the empirical results are given in the fourth section.

\section{THE THEORETICAL AND EMPIRICAL BACKGROUNDS OF THE NEW KEYNESIAN PHILLIPS CURVE}

\section{The Theoretical Framework}

The NKPC represents the outcome of convergence between neoclassical and Keynesian theories. By connecting the rational expectation hypothesis, as the "trademark" of New Classical Macroeconomics, with price and wage rigidity models, New Keynesians have made a step closer to the New Consensus Macroeconomics. Inflation dynamics modelling in the New Consensus is dominantly based on the NKPC (Galí, 2008). The actual inflation rate $\left(\pi_{t}\right)$ is determined by the present expectations of a future inflation rate $\left(E_{t} \pi_{(t+1)}\right)$, which is in line with the rational expectation hypothesis. The impact of changes in the real economy on the actual inflation rate is captured by the second component, which basically refers to real marginal costs dynamics $\left(m c_{t}\right)$. Accordingly, the NKPC can be expressed as follows (Galí, 2008):

$$
\pi_{t}=\beta E_{t}\left(\pi_{t+1}\right)+\lambda m c_{t^{\prime}}
$$

where $\beta$ measures the impact of the expected future inflation rate on the actual rate, whereas $\lambda$ represents the frequency of the price change, thus reflecting the impact of real marginal costs on the inflation rate. Marginal cost changes are determined by the productivity and production capacity utilization rate, as well as input prices, which may all lead to costpush inflation. Beside the NKPC with marginal costs, there is also a version with the output gap (a deviation of the actual output from the potential). Namely, if the following is assumed:

$$
m c=\kappa\left(y_{t}-y_{t}^{*}\right),
$$

which means that the relationship between marginal costs and the output gap $\left(y_{t}-y_{t}^{*}\right)$ can be expressed by the parameter $\kappa$, then it follows:

$$
\pi_{t}=\beta E_{t}\left(\pi_{t+1}\right)+\lambda \kappa\left(y_{t}-y_{t}^{*}\right)
$$

where $y_{t}$ and $y_{t}^{*}$ refer to the actual and potential outputs, respectively (Galí, 2008). The positive output gap occurs when aggregate demand exceeds potential supply, thus creating inflationary pressure. In contrast, an insufficient level of aggregate demand results in a negative output gap, which decreases the inflation rate (Orphanides \& van Norden, 2005).

\section{An Overview of the Empirical Research}

Since this study investigates the original form of the NKPC for a closed economy, the current section is 
focused on recent research studies dealing with the role of domestic inflation drivers and asymmetries in their effects on inflation.

Using different alternatives for the output gap, S. Oinonen and M. Pallovita (2014) find that the negative output gap in the euro area existent since 2012 has lowered the inflation rate below the policy target and that the Phillips curve has become steeper. C. Friedrich (2016) applies the factor model to estimate the Phillips curve for 25 advanced economies. He concludes that, apart from the output gap, the inclusion of inflation expectations into this relationship improves the explanation of inflation dynamics. Analyzing the NKPC in the USA, Q. Xu, X. Niu, C. Jiang, and X. Huang (2015) document that an increase in the output gap leads to a higher level of inflation and raises its volatility. M. Jarociński and M. Lenza (2018) assess the euro area output gap as a factor of inflation dynamics. They conclude, inter alia, that an increase in aggregate demand may reduce the output gap after 2011, which wouldn't be coupled with an increase in inflation. M. Jašová, R. Moessner and E. Takáts (2018) analyze the impact of domestic output gaps on inflation in 25 developed and 22 emerging economies. Comparing these effects with the impact of the global output gap, they conclude that both of them were and are important inflation drivers before the Great Recession of 2008 and in the post-crisis period as well, respectively.

Whereas the significance of the output gap as a determinant of the dynamics of the inflation rate is mainly confirmed by numerous empirical studies, the findings related to the validity of the NKPC with marginal costs included are diversified and usually depend on the choice of the analyzed economy. For example, S. Lagoa (2014) finds the evidence that nominal unit labour costs, along with a long-term discrepancy between prices and costs, could explain inflation differentials in the euro area. J. Posh and F. Rumler (2014) estimate a hybrid NKPC with the openeconomy measure of marginal costs. Their model provides a good explanation of inflation changes in the United Kingdom, but only in the short run. In contrast, S. Mazumder (2012) shows that real unit labour costs cannot explain the inflation dynamics in the European economies; these costs are also a poor proxy for real marginal costs. Similar findings for the USA can be found in E. V. Peneva and J. B. Rudd (2017). These controversies stimulate a certain additional research study based on a different methodology in order to generate more valid and unambiguous conclusions about the impact of these costs on the inflation rate.

Opposite to the research studies dealing with developed economies, the studies of the NKPC in (former) transition countries do not find enough evidence of the importance of inflation expectations and real marginal costs, but rather frequently emphasize a higher extent of price rigidity. Thus, A. Dabušinskas and D. Kulikov (2007) develop the Phillips curve model for the Baltic economies (Estonia, Latvia, and Lithuania) and conclude that actual inflation is mainly determined by past rates and, to a lesser extent, by expected future inflation, whereas the impact of real marginal costs is not significant. B. Vašíček (2011) comes to a similar conclusion for Visegrád Group, A. Vasilev (2015) for Hungary and F. Furuoka (2016) for the Baltic States. In contrast, M. Bouda (2013) finds the evidence of the key impact of expected inflation, along with monetary policy shocks, on the actual inflation rate in the Czech Republic. M. Basarac, B. Škrabić and P. Sorić (2011) analyze the hybrid Phillips curve in nine transition economies and confirm the fact that actual inflation is associated with expected inflation and the output gap in the long run.

In recent years, many empirical studies have investigated nonlinearity (asymmetry) in the relationship between the variables of the Phillips curve and the inflation rate. For instance, P. G. Egan and A. J. Leddin (2017) investigate inflation dynamics in China and conclude that the inflation-output relationship is nonlinear. Analyzing unemployment fluctuations in the New Keynesian model, A. Lepetit (2018) investigates the role of the labor market asymmetries in designing efficient monetary policy measures. He concludes that this asymmetry is the key determinant of the inflation-unemployment relationship and that the monetary policy should be directed towards both inflation and unemployment. 
Employing the NARDL model and the methods of causality, M. E. Bildirici and F. Özaksoy Sonustun (2018) investigate the inflation-unemployment nexus in Japan, Turkey, the USA and France. The empirical estimates indicate a negative and asymmetric longterm relationship between these variables. J. Morley and I. B. Panovska (2019) assess the business cycle asymmetry in ten industrialized economies. They reveal that the output gap responds more intensively during recessions than in expansions, thus indicating that the Phillips curve is mainly convex. A research study conducted by S. Ho and B. N. Iyke (2019) also confirms the nonlinearity of the Phillips curve in 11 Eurozone countries and indicates that the inflation-unemployment nexus is negative when the unemployment rate is lower than $5 \%$.

Having in mind the empirical research studies carried out to date, this study aims to supplement the literature dealing with the role and significance of asymmetric effects in the NKPC in transition economies by focusing on the Republic of Serbia's economy. The empirical results may improve the understanding of the inflation process and may serve monetary authorities in setting more efficient measures aimed at achieving and maintaining monetary stability.

\section{RESEARCH METHODOLOGY AND DATA}

\section{The Econometric Model}

The main problem in the empirical analysis of the validity of the New Phillips curve (Equation 1), reflects a fact that the data about real marginal costs are not available. Instead, J. Galí and M. Gertler (1999) proposed that unit labor costs should be used, which has become the approach commonly used in empirical research studies (Furuoka, 2016; Peneva \& Rudd, 2017; Chin, 2018). These authors employ average labor costs instead of real marginal costs, which is defined as the total labor share in the nominal output:

$$
m c_{t}=\frac{w_{t} n_{t}}{p_{t} y_{t}}
$$

where $w_{t}$ denotes the nominal wage, $n_{t}$ stands for employment, $p_{t}$ is the price level, and $y_{t}$ represents the output.

The total labor share in the nominal output can be perceived as the real unit labor cost $\left(\varphi_{t}\right)$, which justifies its use instead of the real marginal cost. Furthermore, for the purpose of the empirical analysis conducted in this paper, Equation (1) can be extended by introducing an intercept $\left(\alpha_{0}\right)$, which indicates the inflation rate consistent with the zero value of the explanatory variables, as well as by adding a random error $\left(\varepsilon_{t}\right)$, in order to generate the following equation:

$$
\pi_{t}=\alpha_{0}+\beta_{1} \pi_{t}^{e}+v \varphi_{t}+\varepsilon_{t^{\prime}}
$$

where $\pi_{t}^{e}$ denotes expected future inflation, whereas the coefficient $v$ measures the effect of change in the unit labour costs on the inflation rate.

Likewise, Equation (3) can be reformulated so as to generate an NKPC model for empirical estimation as follows:

$$
\pi_{t}=\alpha_{1}+\beta_{2} \pi_{t}^{e}+\gamma x_{t}+\varepsilon_{t^{\prime}}
$$

where $x_{t}$ denotes the output gap $\left(x_{t} \equiv y_{t}-y_{t}^{*}\right)$.

The empirical analysis carried out in this study is based on the Autoregressive Distributive Lag (ARDL) approach. Since the lagged values of the dependent and explanatory variables serve as regressors, the model introduces dynamics into their relationship, thus helping eliminate the problem with the autocorrelation of residuals (Moosa, 1997).

Starting from Equation (5), the Autoregressive Distributed Lag (ARDL) model $(m, n)$ of the NKPC can be expressed as follows:

$$
\begin{gathered}
\Delta \pi_{t}=\alpha_{0}+\beta_{1} \pi_{t-1}+\delta_{1} \pi_{t-1}^{e}+v \varphi_{t-1}+ \\
\sum_{j=1}^{m} \vartheta_{j} \Delta \pi_{t-j}+\sum_{j=0}^{n} \tau_{j} \Delta \varphi_{t-j}+\varepsilon_{t}
\end{gathered}
$$

where $\Delta$ is the first difference operator, $\beta_{1}, \delta_{1}$ and $v$ are the long-term coefficients, $\vartheta$ and $\tau$ denote the short- 
term coefficients, whereas $m$ and $n$ are the selected lag length.

It is evident that the expected inflation rate $\left(\pi^{e}\right)$ serves as a fixed regressor, i.e. its impact is modelled without the distributed lags that cover the short-term relationship. This allows the modelling of the longterm relationship between change in actual inflation in the observed quarter and expected inflation in the same quarter of the next year, since the analyzed data are structured in such a way.

In order to test the second research hypothesis, it is necessary to decompose the dynamics of unit labor costs into positive and negative changes, on the one hand, and reveal their impact on the inflation rate, on the other. Changes in real unit labor costs $\left(\varphi_{t}\right)$ are decomposed into increasing and decreasing partial sums, i.e. $\varphi_{t}=\varphi+\varphi_{t}^{+}+\varphi_{t}^{\text {; }}$, where $\varphi_{t}^{+}$and $\varphi_{t}^{-}$represent the partial sums of positive and negative changes in real unit labour costs, generated as follows (Shin et al, 2014):

$$
\begin{aligned}
& \varphi_{t}^{+}=\sum_{j=0}^{t} \Delta \varphi_{j}^{+}=\sum_{j=0}^{t} \max \left(\Delta \varphi_{j}, 0\right) \\
& \varphi_{t}^{-}=\sum_{j=0}^{t} \Delta \varphi_{j}^{-}=\sum_{j=0}^{t} \min \left(\Delta \varphi_{j}, 0\right)
\end{aligned}
$$

By substituting $\varphi_{t}$ in Equation (7) by $\varphi_{t}^{+}$and $\varphi_{t}^{-}$, the NARDL model is obtained in the following form:

$$
\begin{aligned}
& \Delta \pi_{t}=\alpha_{0}+\beta_{1} \pi_{t-1}+\delta_{1} \pi_{t-1}^{e}+v^{+} \varphi_{t-1}^{+}+v^{-} \varphi_{t-1}^{-}+ \\
& \sum_{j=1}^{m} \vartheta_{j} \Delta \pi_{t-j}+\sum_{j=0}^{n}\left(\tau_{j}^{+} \Delta \varphi_{t-j}^{+}+\tau_{j}^{-} \Delta \varphi_{t-j}^{-}\right)+\varepsilon_{t}
\end{aligned}
$$

Likewise, starting from Equation (6), the ARDL $(p, q)$ model of the NKPC can be expressed as follows:

$$
\begin{aligned}
& \Delta \pi_{t}=\alpha_{1}+\beta_{2} \pi_{t-1}+\delta_{2} \pi_{t-1}^{e}+\gamma x_{t-1}+ \\
& \sum_{i=1}^{p} \kappa_{i} \Delta \pi_{t-i}+\sum_{i=0}^{q} \mu_{i} \Delta x_{t-i}+\varepsilon_{t}
\end{aligned}
$$

where $\beta_{2}, \delta_{2}$ and $\gamma$ denote the long-term coefficients, $\kappa$ and $\mu$ are the short-term coefficients, and $p$ and $q$ are the selected lag length.

The changes in the output gap $\left(\mathrm{x}_{t}\right)$ are decomposed into increasing $\left(\mathrm{x}_{t}^{+}\right)$and decreasing $\left(\mathrm{x}_{t}^{-}\right)$partial sums in the following way:

$$
\begin{aligned}
& x_{t}^{+}=\sum_{i=0}^{t} \Delta x_{i}^{+}=\sum_{i=0}^{t} \max \left(\Delta x_{i}, 0\right) \\
& x_{t}^{-}=\sum_{i=0}^{t} \Delta x_{i}^{-}=\sum_{i=0}^{t} \min \left(\Delta x_{i}, 0\right)
\end{aligned}
$$

In order to test the third research hypothesis, the NARDL model of the NKPC with the output gap is obtained by replacing $x_{t}$ with $x_{t}^{+}$and $x_{t}^{-}$in Equation (10):

$$
\begin{aligned}
& \Delta \pi_{t}=\alpha_{1}+\beta_{2} \pi_{t-1}+\delta_{2} \pi_{t-1}^{e}+ \\
& \gamma^{+} x_{t-1}^{+}+\gamma^{-} x_{t-1}^{-}+\sum_{i=1}^{p} \kappa_{i} \Delta \pi_{t-i}+ \\
& \sum_{i=0}^{q}\left(\mu_{i}^{+} \Delta x_{t-i}^{+}+\mu_{i}^{-} \Delta x_{t-i}^{-}\right)+\varepsilon_{t}
\end{aligned}
$$

The presence of cointegration between the inflation rate and the explanatory variables is investigated by employing the Bounds test, developed by $\mathrm{M}$. H. Pesaran, Y. Smit and R. J. Shin (2001). The null hypotheses of no cointegration in Equations (9) and (12), i.e. $\mathrm{H}_{0}: \beta_{1}=\delta_{1}=v^{+}=v^{-}=0$ and $\mathrm{H}_{0}: \beta_{2}=\delta_{2}=\gamma^{+}$ $=\gamma^{-}=0$, respectively, are tested in order to obtain the value of the F-statistic. The presence of the long-term asymmetry is checked by testing the null hypothesis of equality between the long-term coefficients of positive and negative changes in unit labor costs, i.e. $\mathrm{H}_{0}: L_{\varphi}^{+}=L_{\varphi}^{-}\left(\right.$where $L_{\varphi}^{+}=-v^{+} / \beta_{1}$ and $\left.L_{\varphi}^{-}=-v^{-} / \beta_{1}\right)$ and the null hypothesis of equality between the longterm coefficients of positive and negative changes in the output gap, $\mathrm{H}_{0}: L_{x}^{+}=L_{x}^{-}$(where $L_{x}^{+}=-\gamma^{+} / \beta_{2}$ and $\left.L_{x}^{-}=-\gamma^{-} / \beta_{2}\right)$. The rejection of the null hypotheses at a given level of statistical significance indicates that the association between the inflation rate and the considered regressors is asymmetric in the long run. The presence of short-term asymmetry is evaluated by testing the null hypotheses of symmetry in Equations (9) and (12), i.e. $\mathrm{H}_{0}: \sum_{j=0}^{n} \tau_{j}^{+}=\sum_{j=0}^{n} \tau_{j}^{-}$and $\mathrm{H}_{0}: \sum_{i=0}^{q} \mu_{i}^{+}=\sum_{i=0}^{q}$ $\mu_{i}^{-}$, respectively. To test the hypotheses, the Wald test is employed as a common approach in a number of empirical studies (Shin et al, 2014; Bildirici \& Özaksoy, 2018).

In order to have the insight into the cumulative impact of short- and long-term changes in the explanatory variables on the inflation rate, dynamic multipliers are applied (Shin et al, 2014). They capture the effects of a $1 \%$ increase and decrease in unit labor costs and the output gap on the inflation rate. 


\section{The Dataset}

Quarterly data about the year-on-year actual and expected inflation rates (12 months ahead, enterprises' expectations), the real indices of unit labor costs in industry, and the real Gross Domestic Product (GDP) are used in this empirical study. The data were collected from the National Bank of Serbia and the Eurostat databases. The analysis covers the time span from the first quarter of 2008 to the fourth quarter of 2019 (48 observations). Bearing in mind the fact that the data on the dynamics of the inflation rate, expected inflation and unit labor costs indices are available on a monthly basis, the average observation approach was applied in order to obtain such quarterly data. The output gap was calculated by decomposing the real GDP time series into the trend and cyclical components by means of the HodrickPrescott filter $(\lambda=1600)$.

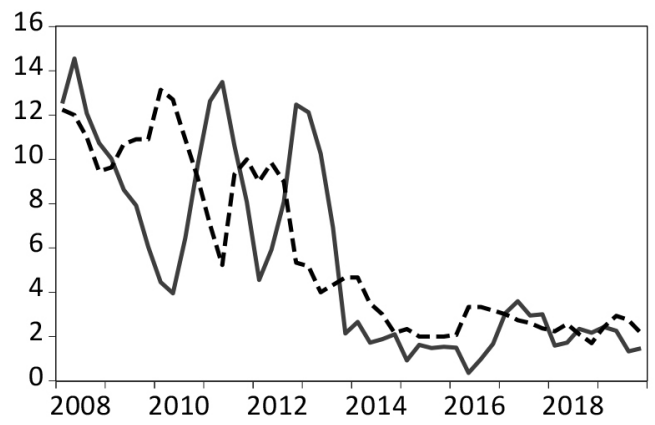

Actual inflation rate - - Expected inflation rate
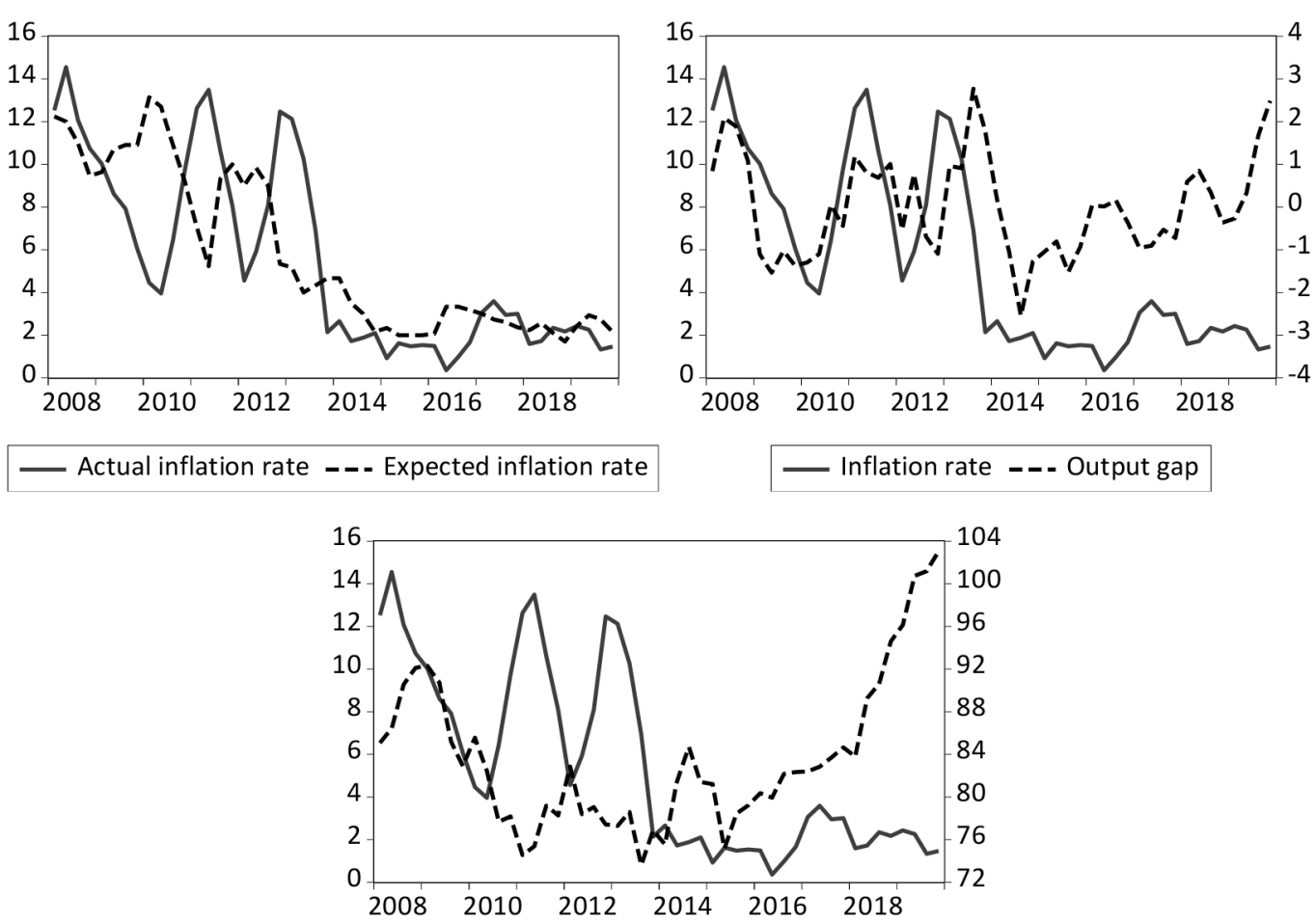

_ Inflation rate $\ldots$ - - Real unit labour costs $(2019=100)$

Figure 1 The empirical dynamics of the analyzed variables in the Republic of Serbia

Source: Author, based on the National Bank of Serbia's data
The empirical dynamics of the observed variables in the analyzed time period are presented in Figure 1. A common trend between the expected and actual inflation rates is apparent, as well as their approaching after 2014. It could be the initial signal for the statistical significance of their relationship. The positive association between the output gap and the inflation rate after 2014 is also evident, whereas the exact direction of the unit labor costs-inflation rate nexus is not visually apparent. The preliminary analysis of the relationships between the observed variables by means of the scatter diagrams (Figure 2) indicates a positive association between the inflation rate and all the explanatory variables, except for the unit labor costs, which are negatively correlated with the inflation rate. This analysis does not necessarily prejudice the final results, as the dynamics of the explanatory variables are decomposed into positive and negative changes serving as separate regressors.

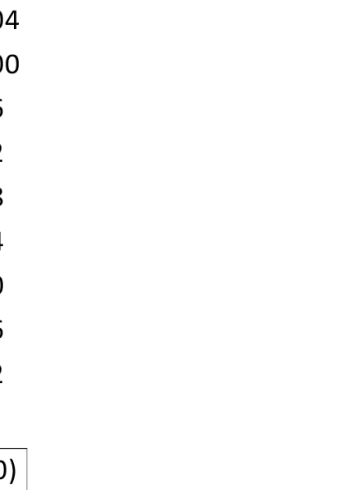



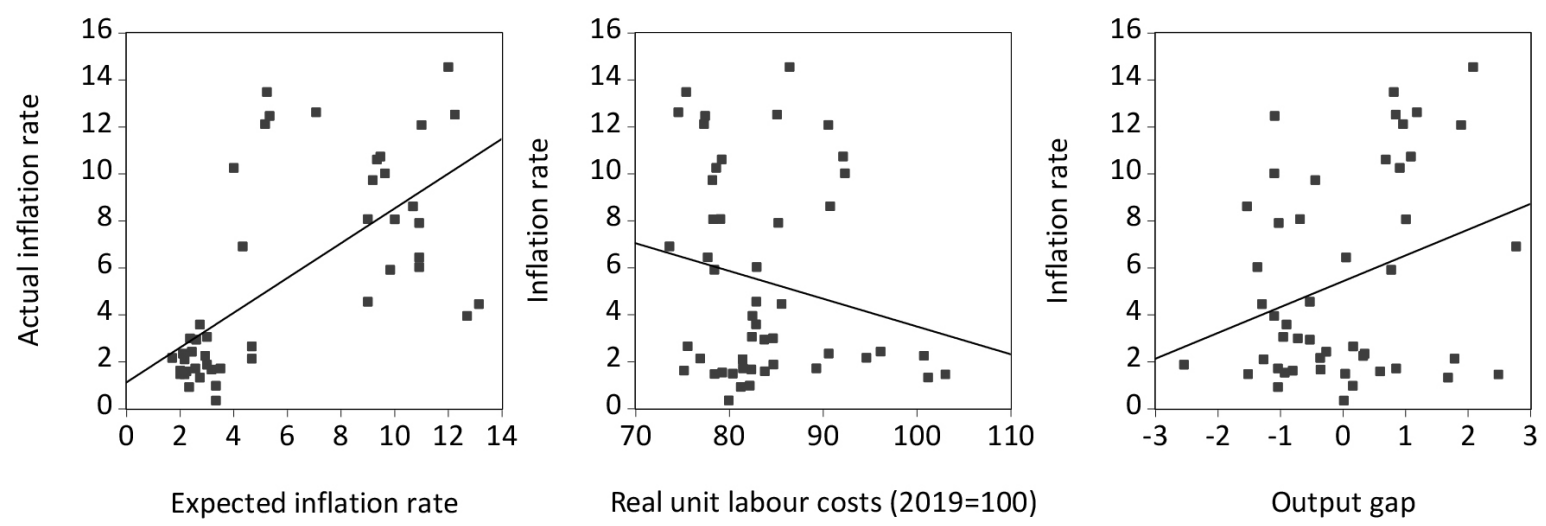

Figure 2 The scatter diagrams of the relationship between the inflation rate and the explanatory variables

Source: Author, based on the National Bank of Serbia's data

\section{RESEARCH RESULTS AND DISCUSSION}

A valid implementation of the NARDL model implies that all variables should be stationary at the level and/ or first difference, which entails the application of different unit root tests as the first step. The results of the parametric ADF (Augmented Dickey-Fuller) test and the nonparametric PP (Phillips-Perron) test reported in Table 1 confirm that this condition is fulfilled. In order to obtain more robust results, the Zivot-Andrews test (Zivot \& Andrews, 1992), which takes into account the presence of structural breaks, is also applied. This test re-confirms the fact that none of the observed time series is I(2). The results of this test also indicate the exact break date (quarter)used as a dummy variable in the further analysis. This variable takes the value 0 before the break date and the value 1 afterwards.

Prior to the final estimation of the NARDL model, the direction of the causality between the analyzed variables should be checked. The inflation rate is set as a dependent variable in all versions of the Phillips curve, including the New Keynesian one. Accordingly, the Granger non-causality test is applied in order to evaluate whether changes in the inflation rate can be explained by past changes in unit labor costs and the output gap. Since unit root tests indicate the fact that the time series integrated are of a different order $(\mathrm{I}(0)$ and/or I(1)), the Toda-Yamamoto procedure is applied as well (Toda \& Yamamoto, 1995). This procedure checks the causality between time series at levels, thus reducing the risk of the wrong identification of their exact integration order (Wolde-Rufael, 2005). In addition, following A. Hatemi-J (2012), the direction of the causality between positive and negative changes in unit labor costs (the output gap) and the inflation rate is investigated.

The causality test results reported in Table 2 confirm the presence of the unidirectional causality which goes from the real unit labor costs and the output gap to the actual inflation rate. The positive and negative changes in these variables also represent an important determinant of the dynamics of the future inflation rate. The actual inflation rate is led by expected inflation as well. Hence, the postulated relationship between the inflation rate and the explanatory variables in the NKPC is appropriate for Serbia's economy.

The final specification of the NARDL model for both variants of the NKPC is reported in Table 3. It is obtained by the successive trimming of insignificant time lags, starting from four lags. The residual diagnostics tests (for normality, autocorrelation, heteroscedasticity, dynamic stability, and the functional form) all indicate the fact that both models are well specified and stable. The results of the cointegration test in the bottom row of Table 3 confirm 
Table 1 The results of the unit root tests

\begin{tabular}{c|cc|cc|cc}
\hline \multirow{2}{*}{ Variable } & \multicolumn{2}{|c|}{ ADF test } & \multicolumn{2}{c|}{ PP test } & \multicolumn{2}{c}{ Zivot-Adrews test } \\
& Constant & $\begin{array}{c}\text { Constant } 8 \\
\text { Trend }\end{array}$ & Constant & $\begin{array}{c}\text { Constant \& } \\
\text { Trend }\end{array}$ & t-statistic & Break date \\
\hline$\pi$ & -1.66 & -2.57 & -1.88 & -2.49 & $-4.64^{* * *}$ & $2014 \mathrm{Q} 2$ \\
$\pi^{e}$ & -1.28 & -2.21 & -1.56 & -2.21 & $-4.95^{* * *}$ & $2012 \mathrm{Q} 4$ \\
$x$ & $-2.88^{*}$ & -2.84 & $-2.97^{* *}$ & -3.01 & $-3.95^{* * *}$ & $2014 \mathrm{Q} 2$ \\
$\varphi$ & -1.17 & -0.99 & -1.17 & -0.87 & $-2.69^{*}$ & $2010 \mathrm{Q} 2$ \\
$\Delta \pi$ & $-2.80^{*}$ & -2.81 & $-3.99^{* * *}$ & $-4.02^{* *}$ & $-3.59^{* * *}$ & $2013 \mathrm{Q} 1$ \\
$\Delta \pi^{e}$ & $-5.95^{* * *}$ & $-6.08^{* * *}$ & $-5.76^{* * *}$ & $-5.73^{* * *}$ & -6.81 & $2013 \mathrm{Q} 3$ \\
$\Delta x$ & $-5.66^{* * *}$ & $-5.47^{* * *}$ & $-6.69^{* * *}$ & $-6.74^{* * *}$ & $-6.12^{*}$ & $2013 \mathrm{Q} 4$ \\
$\Delta \varphi$ & $-6.94^{* * *}$ & $-7.31^{* * *}$ & $-6.93^{* * *}$ & $-7.81^{* * *}$ & $-4.83^{* *}$ & $2015 \mathrm{Q} 2$ \\
\hline
\end{tabular}

Note: The results denoted by *, **, and *** are statistically significant at the levels of $10 \%, 5 \%$, and $1 \%$, respectively.

Source: Author

the presence of the long-term relationship between the dependent and explanatory variables in both models. The impact of expected inflation on the actual inflation rate is statistically significant in both models, too. In the first model, the long-term coefficient of the negative changes in the unit labor costs $\left(L_{\varphi}^{-}\right)$is statistically significant and larger than the long-term coefficient of the positive changes $\left(L_{\omega}^{+}\right)$. More precisely, a $1 \%$ increase in the unit labor cost leads to the $0.28 \%$ growth of the inflation rate, whereas a $1 \%$ decrease in these costs leads to a $0.61 \%$ fall in the inflation rate. The results of the Wald test (WLR) confirm the presence of a long-term asymmetry in the relationship between the unit labor costs and the inflation rate. Bearing in mind the fact that the dynamics of these costs are determined by the changes in productivity, it appears that the improvement of productivity might reduce cost-push inflation growth as a component of the total inflation in the Republic of Serbia.

In the second model, the impact of both longterm coefficients is statistically significant, and the

Table 2 The results of the Granger non-causality test (the Toda-Yamamoto procedure)

\begin{tabular}{cc|cc|cc}
\hline \multicolumn{2}{c|}{ Symmetric approach } & \multicolumn{2}{c|}{$\begin{array}{c}\text { Asymmetric approach - positive } \\
\text { changes in the explanatory variables }\end{array}$} & \multicolumn{2}{c}{$\begin{array}{c}\text { Asymmetric approach - negative } \\
\text { changes in the explanatory variables }\end{array}$} \\
\hline$H_{0}$ & $\chi^{2}$ & $H_{0}$ & $\chi^{2}$ & $H_{0}$ & $\chi^{2}$ \\
$\varphi \rightarrow \pi$ & $7.57^{*}$ & $\varphi^{+} \rightarrow \pi$ & $8.06^{*}$ & $\varphi+\pi$ & $5.89^{*}$ \\
$\pi \rightarrow \varphi$ & 1.20 & $\pi \rightarrow \varphi^{+}$ & 1.29 & $\pi \rightarrow \varphi$ & 3.85 \\
$x \rightarrow \pi$ & $2.81^{*}$ & $X^{+} \rightarrow \pi$ & 6.09 & $x \rightarrow \pi$ & $5.91^{*}$ \\
$\pi \rightarrow x$ & 1.12 & $\pi \rightarrow x^{+}$ & 3.52 & $\pi \rightarrow x$ & 1.96 \\
$\pi^{e} \rightarrow \pi$ & $6.40^{* *}$ & - & - & - & - \\
$\pi \rightarrow \pi^{e}$ & 2.13 & - & - & - & - \\
\hline
\end{tabular}

Notes: The symbol $\rightarrow$ means "do not Granger-cause"; the results denoted by ${ }^{*} .{ }^{* *}$. and ${ }^{* * *}$ are statistically significant at the levels of $10 \% .5 \%$. and $1 \%$. respectively.

Source: Author 
Table 3 The NARDL model specification of the NKPC

\begin{tabular}{|c|c|c|c|c|c|}
\hline \multicolumn{3}{|c|}{ Model with unit labor costs } & \multicolumn{3}{|c|}{ Model with the output gap } \\
\hline Variable & Coefficient & $\mathrm{p}$-value & Variable & Coefficient & $\mathrm{p}$-value \\
\hline$\alpha_{0}$ & 2.48 & 0.26 & $\alpha_{1}$ & 2.52 & 0.28 \\
\hline$\pi_{(t-1)}$ & -0.39 & 0.00 & $\pi_{(t-1)}$ & -0.64 & 0.00 \\
\hline$\pi_{(t-1)}^{e}$ & 0.25 & 0.05 & $\pi_{(t-1)}^{e}$ & 0.37 & 0.00 \\
\hline$\varphi_{(\mathrm{t}-1)}^{+}$ & 0.11 & 0.06 & $X^{+}{ }_{(t-1)}$ & 0.69 & 0.00 \\
\hline$\varphi_{(\mathrm{t}-1)}^{-}$ & 0.23 & 0.00 & $x_{(t-1)}$ & 0.81 & 0.00 \\
\hline$\Delta \pi_{(t-1)}$ & 0.57 & 0.00 & $\Delta \pi_{(t-1)}$ & 0.67 & 0.00 \\
\hline$\Delta \varphi_{t}^{+}$ & -0.22 & 0.08 & $\Delta \pi_{(t-2)}$ & 0.51 & 0.00 \\
\hline$\Delta \varphi_{t}$ & 0.07 & 0.62 & $\Delta x_{t}^{+}$ & 0.46 & 0.12 \\
\hline$\Delta \varphi_{(\mathrm{t}-2)}$ & -0.27 & 0.02 & $\Delta x_{(t-1)}$ & -1.23 & 0.00 \\
\hline$D$ & 4.19 & 0.00 & $D$ & - & - \\
\hline$L_{\varphi}^{+}$ & 0.28 & 0.11 & $L_{x}^{+}$ & 1.09 & 0.00 \\
\hline$L_{\varphi}$ & 0.61 & 0.00 & $L_{x}$ & 1.28 & 0.00 \\
\hline $\mathrm{R}^{2}$ (adjusted) & \multicolumn{2}{|c|}{0.65} & $\mathrm{R}^{2}$ (adjusted) & \multicolumn{2}{|c|}{0.68} \\
\hline JB test & 0.80 & 0.67 & JB test & 1.13 & 0.57 \\
\hline BG LM test & 1.17 & 0.32 & BG LM test & 1.44 & 0.25 \\
\hline BPG test & 0.31 & 0.97 & BPG test & 1.98 & 0.08 \\
\hline Cusum test & \multicolumn{2}{|c|}{ Stable } & Cusum test & \multicolumn{2}{|c|}{ Stable } \\
\hline Cusum Sq. test & \multicolumn{2}{|c|}{ Stable } & Cusum Sq. test & \multicolumn{2}{|c|}{ Stable } \\
\hline RESET test & 0.74 & 0.39 & RESET test & 0.22 & 0.64 \\
\hline$W_{L R}$ & 11.56 & 0.00 & $W_{L R}$ & 1.29 & 0.26 \\
\hline$W_{S R}$ & 0.01 & 0.95 & $W_{S R}$ & 14.48 & 0.00 \\
\hline$F_{P S S}$ & 11.89 & 0.00 & $F_{P S S}$ & 20.06 & 0.00 \\
\hline
\end{tabular}

Notes: $D$ denotes the dummy variable representing the structural break in the time series; JB, BG LM, and BPG are the Jarque-Bera test for normality, the Breusch-Godfrey test for autocorrelation, and the Breusch-Pagan-Godfrey test for the heteroscedasticity of the residuals, respectively; Cusum (Cusum Squared) refers to the cumulative sum of the residuals (squared residuals) test, which is presented graphically in the appendix; $\mathrm{W}_{\mathrm{LR}}$ and $\mathrm{W}_{\mathrm{SR}}$ denote the results of the short- and long-term asymmetry Wald tests, respectively; $F_{\text {PSS }}$ refers to the F-statistic of the Bounds test (Pesaran et al, 2001).

Source: Author

coefficient of the negative changes $\left(L_{x}^{-}\right)$is higher than the coefficient of the positive changes $\left(L_{x}^{+}\right)$: a $1 \%$ decrease in the output gap leads to a $1.28 \%$ fall in inflation, whereas a $1 \%$ increase leads to the $1.09 \%$ growth of the inflation rate. However, the result of the Wald test indicates no statistically significant difference between the two coefficients, i.e. the relationship between the output gap and inflation is symmetric in the long run.
If the fact that unit labor costs represent a good approximation for marginal costs is accepted, then it can be concluded that the results pertaining to the long-term relationship in both models of the Phillips curve are mutually consistent, since the negative changes in the output gap (in economic contraction) coincide with a decrease in the marginal cost due to a decrease in the production capacity utilization rate. 
Indeed, these procyclical dynamics of marginal costs are proven in numerous empirical studies (Alexová, 2012; Vasilev, 2015; Furuoka, 2016).

Furthermore, the Wald test for a short-run asymmetry (WSR) reveals the fact that the relationship between the output gap and the inflation rate is asymmetric in the short run, which is opposite to the results for the model with the unit labor costs. The short-term asymmetry in the relationship between the output gap and inflation is a corollary of an incomplete inflation adjustment during economic expansion and contraction due to a certain extent of the price rigidity, which is in accord with the NKPC.

An insight into the cumulative impact of explanatory variables in the NKPC, as well as the adjustment from the initial shock towards a long-term equilibrium, can be gained by means of dynamic multipliers (Shin et al, 2014). Figure 3a represents the intertemporal effects of the unit labor costs increases and decreases on the inflation rate. The negative changes in these costs (the dashed grey line) lead to the inflation rate reduction, which is more pronounced in the short run (approximately during five quarters after the initial shock) and gradually decreases towards the long-
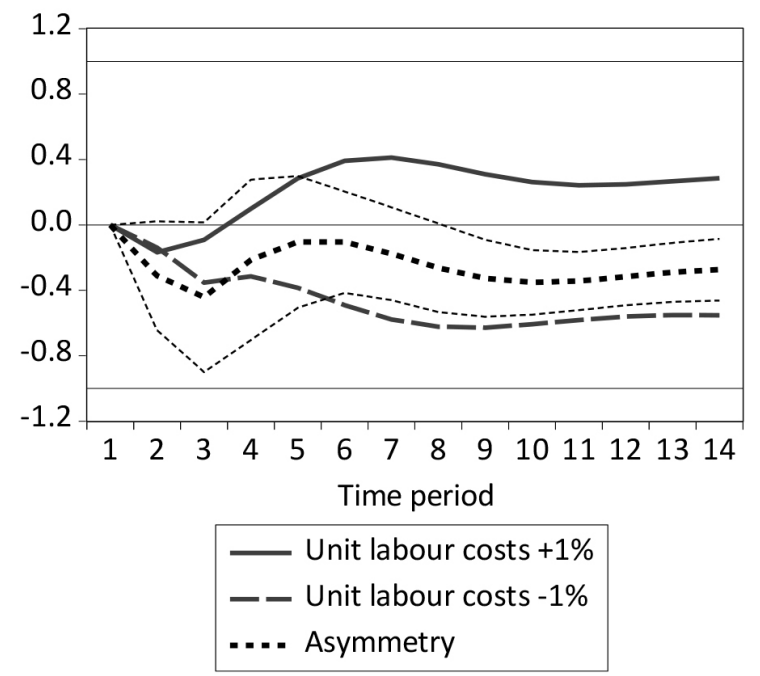

(a) term equilibrium. The positive changes in the unit labor costs (the continuous grey line) initially lead to the inflation rate reduction, and later to a long-term inflation increase. The dashed black line represents the difference between the effects of the positive and negative changes, i.e. the asymmetry. It is presented along with the black dashed lines denoting the $95 \%$ confidence interval. If the zero line is inside the confidence interval, then there is no asymmetry. The dynamic multipliers in Figure 3a indicate a long-term asymmetry, but a short-term symmetry, which is in accord with the results of the Wald test from Table 3. The long-term equilibrium establishes approximately 10 quarters after the initial change in the unit labor costs.

In Figure 3b, the short- and long-term impacts of the changes in the output gap on the inflation rate are presented. The short-term asymmetry is apparent and the dominance of the positive changes in the output gap is followed by the dominance of the negative changes. In the first three quarters, the decrease in the output gap leads to the growth of the inflation rate and then to its fall. Thus, the inflation rate strongly responds in the short run, but much more time is needed for a long-term equilibrium to establish.

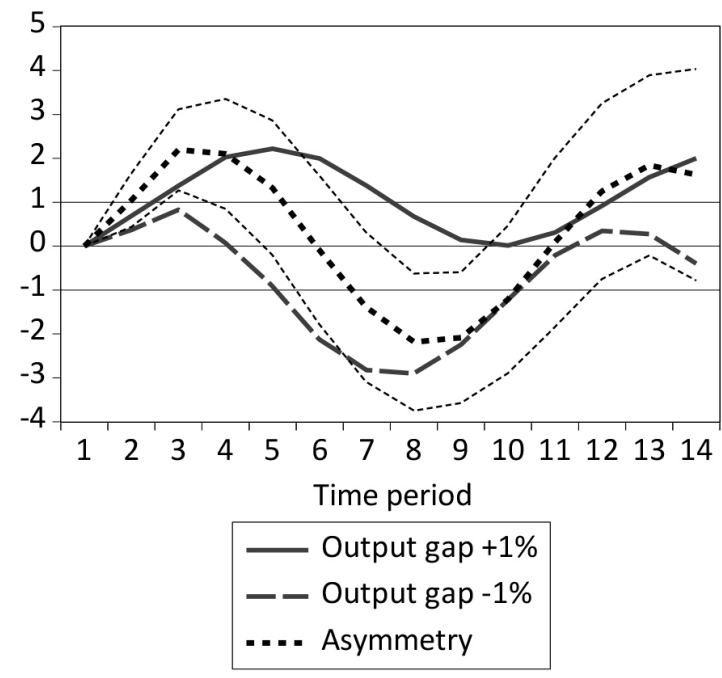

(b)

Figure 3 The dynamic impact of the changes in the unit labor costs (a) and the output gap (b) on the inflation rate 
The dynamic multipliers confirm the Wald test results pertaining to the presence of a short-term asymmetry.

In the light of the defined research hypotheses, the results of the empirical analysis can be summarized as follows. In both models of the NKPC, the current expectations of the future inflation rate have a statistically significant impact on the actual inflation rate, thus confirming the first research hypothesis. The values of the expected inflation coefficients are relatively low ( 0.25 in the first, and 0.37 in the second model), thus indicating the fact that the inflation expectations of economic agents in the Republic of Serbia are formed following an adaptive pattern, i.e. they are based on past inflation rates. These results coincide well with the findings for other transition and emerging economies (Dabušinskas \& Kulikov, 2007; Vašiček, 2010; Basarac et al, 2011; Furuoka, 2016).

The empirical analysis has not provided enough evidence for the second research hypothesis to be accepted. Unit labor costs have a statistically significant and positive long-term impact on the inflation rate in the Republic of Serbia, but only during economic contraction. An increase in these costs during economic expansion has no statistically significant impact on inflation growth. Their long-term effect on the inflation rate in Serbia is asymmetric, which is in contrast with the NKPC.

Changes in the output gap have a statistically significant impact on the inflation rate in the Republic of Serbia, which is also symmetric during expansionary and contractionary periods. This impact is positive, i.e. the inflation rate moves procyclically (it increases in expansion, and decreases in contraction). Thus, the third research hypothesis is confirmed. Given the fact that, in the NKPC model with the output gap, expected future inflation also has a statistically significant impact on the actual inflation rate, it can be concluded that the validity of this variant of the Phillips curve in the context of the Republic of Serbia is confirmed. In other words, this relation of the Phillips curve may serve the Serbian monetary authorities to monitor the impact of changes in the real economy and inflation expectations on the actual inflation rate.
The coefficient of the determination value $\left(\mathrm{R}^{2}\right)$ shows that $68 \%$ of the variation in inflation rates in Serbia can be explained by changes in both the output gap and expected inflation. This is consistent with the finding in a recent study by the World Bank, which indicates the fact that about the three-quarters of the inflation variation are determined by domestic drivers (Ha, Ayhan Kose, Ohnsorge \& Yilmazkuday, 2019). Besides, the difference between the intensity of the long-term impact of the output gap in economic expansion and contraction (the coefficients $\mathrm{L}_{\mathrm{x}}^{+}$and $\mathrm{L}_{\mathrm{x}}$; respectively) implies that the ongoing accommodative monetary policy conducted by the National Bank of Serbia through lowering the reference interest rate can stimulate the economic activity, without creating significant inflationary pressures. This simultaneously coincides with the findings in an empirical study by P. Petrović, D. Brčerević and M. Gligorić (2017) and their conclusion that the ongoing economic growth of the Republic of Serbia is about two percentage points below a potential annual growth of about $5 \%$, i.e. that the output gap is negative. In that case, the monetary expansion would make the actual output closer to the potential, without causing the occurrence of the significant growth of the inflation rate.

\section{CONCLUSION}

This study is aimed at evaluating the validity of the NKPC in the context of the Republic of Serbia and assessing the impact of domestic inflation drivers as well. The results of the estimated NARDL model have indicated the following:

- expected future inflation has a statistically significant impact on the actual inflation rate regardless of the NKPC specification; however, the effect on inflation expectations on the actual inflation rate is less pronounced than the impact of the past inflation;

- real marginal costs, approximated by unit labor costs, exert a statistically significant impact on the inflation rate in the Republic of Serbia, but only during economic contraction. In other words, the 
influence of these costs on the inflation rate is asymmetric in the long run, but symmetric in the short run, which is not in accord with the NKPC. However, as suggested by the identified direction of the asymmetry, the improvement of the productivity level in the long run may decrease cost-push inflation growth as a component of the total inflation;

- changes in the output gap during economic expansion and contraction have a positive, statistically significant and symmetric effect on the inflation rate in the Republic of Serbia, which is consistent with the role of the output gap in the NKPC. The empirical results indicate that inflation responds more intensively to negative than positive supply and demand shocks, i.e. it decreases more significantly in economic contraction than in economic expansion.

Based upon the estimated econometric model of the NKPC, the main contribution of this research study reflects in the quantification of the impact of the domestic inflation drivers in the Republic of Serbia (marginal costs and the output gap) in the different phases of the business cycle, as well as the effect of inflation expectations. In the case of positive and negative unit labor costs and output gap shocks, employing dynamic multipliers, the analysis of the inflation rate adjustment mechanism, could improve the understanding of the cumulative short- and longterm impact of economic disorders on the inflation rate. The estimated model of the NKPC with the output gap provides clear argumentation in favor of the expansionary monetary policy which the National Bank of Serbia has been conducting in recent years, since it can stimulate the economic activity without creating significant inflation pressures.

The empirical analysis conducted in the paper, however, is not without limitations. First of all, the value of the output gap (since it is not directly observable) was obtained by means of the Hodrick-Prescott filter. The application of the other decomposing techniques (such as the Kalman filter, the Band-pass filter, etc.) would potentially result in the different values of the output gap, consequently leading to different estimation results. Furthermore, the analysis is based on unit labor costs for industry, not for the whole economy. In addition, these costs are only used as an approximation for real marginal costs, which there are no available data for. Finally, albeit the research study covers a period of twelve years, the sample is still relatively small (48 observations). Undoubtedly, including more observations would enlighten the relationships among the analyzed variables in a more complete manner.

Some future research in the inflation dynamics in the Republic of Serbia might include the so-called Hybrid NKPC, which incorporates the impact of past inflation on the actual inflation rate, along with inflation expectations. In such a way, the impact of inertia in inflation dynamics as an important aspect of an efficient disinflation policy could be quantified. Although, as in the majority of other economies, domestic inflation drivers significantly determine the variation of inflation rates in the Republic of Serbia, a research study based upon the open-economy NKPC (which includes variables such as an import/export share in the GDP, the oil price, etc.) could identify the key external factors of inflation, thus improving the economic policy directed towards the maintenance of monetary stability.

\section{REFERENCE}

Abdih, Y., Lin. L., \& Paret, A. (2018). Understanding Euro area inflation dynamics: Why so low for so long? IMF Working Paper WP/18/188, Washington.

Alexová, M. (2012). Inflation drivers in new EU members. Working Paper 6/2012, National Bank of Slovakia.

Basarac, M., Škrabić, B., \& Sorić, P. (2011). The hybrid Phillips curve: Empirical evidence from transition economies. Czech Journal of Economics and Finance, 61(4), 367-383.

Bildirici, M. E., \& Sonustun Özaksoy, F. (2018). Backward bending structure of Phillips Curve in Japan, France, Turkey and the U.S.A. Economic Research, 31(1), 537-549. doi: 10.1080/1331677X.2018.1441046 
Bouda, M. (2013). Estimation of the New Keynesian Phillips curve in the Czech environment. Acta Oeconomica Pragensia, 5, 31-46. doi:10.18267/j.aop.414

Chin, K. H. (2018). New Keynesian Phillips curve with timevarying parameters. Empirical Economics, 57(6), 1869-1889. doi:10.1007/s00181-018-1536-2

Dabušinskas, A., \& Kulikov, D. (2007). New Keynesian Phillips curve for Estonia, Latvia and Lithuania. Working Paper 7/2007, Eesti Pank, Bank of Estonia.

Egan, P. G., \& Leddin, A. J. (2017). The Chinese Phillips curve - Inflation dynamics in the presence of structural change. Journal of Chinese Economic and Business Studies, 15(2), 165184. doi:10.1080/14765284.2017.1325597

European Central Bank. (2017). ECB Economic Bulletin, 4/2017.

Friedrich, C. (2016). Global inflation dynamics in the postcrisis period: What explains the puzzles? Economics Letters, 142(C), 31-34. doi:10.1016/j.econlet.2016.02.032

Furuoka, F. (2016). A scientific inquiry on the estimation of the Phillips curve in the Baltic region. Engineering Economics, 27(3), 276-284. doi:10.5755/j01.ee.27.3.6896

Galí, J., \& Gertler, M. (1999). Inflation dynamics: A structural econometric analysis. Journal of Monetary Economics, 44(2), 195-222. doi:10.1016/S0304-3932(99)00023-9

Galí, J. (2008). Monetary Policy, Inflation, and the Business Cycle: An Introduction to the New Keynesian Framework. New Jersey, NJ: Princeton University Press.

Globan, T., Arčabić, V., \& Sorić, P. (2015). Inflation in new EU member states: A domestically or externally driven phenomenon? Emerging Markets Finance and Trade 51(6), 1-15.

Ha, J., Ayhan Kose, M., Ohnsorge, F., \& Yilmazkuday, H. (2019). Sources of inflation: Global and domestic drivers. In J. Ha, M. Ayhan Kose, \& F. Ohnsorge (Eds.). Inflation in Emerging and Developing Economies: Evolution, Drivers, and Policies (pp. 143-199). Washington DC: International Bank for Reconstruction and Development/The World Bank.

Hałka, A., \& Kotłowski, J. (2016). Global or domestic? Which shocks drive inflation in European small open economies? Emerging Markets Finance and Trade, 53(8), 1812-1835. doi:10.1 080/1540496X.2016.1193001

Hatemi-J, A. (2012). Asymmetric causality tests with an application. Empirical economics, 43(1), 447-456. doi:10.1007/ s00181-011-0484-x
Ho, S., \& Iyke, B. N. (2019). Unemployment and inflation: Evidence of a nonlinear Phillips curve in the Eurozone. The Journal of Developing Areas, 53(4), 151-163. doi:10.1353/ jda.2018.0077

Jarociński, M., \& Lenza, M. (2018). An inflation-predicting measure of the output gap in the Euro area. Journal of Money, Credit and Banking, 50(6), 1189-1224. doi:10.1111/jmcb.12496

Jašová, M., Moessner, R., \& Takáts, E. (2018). Domestic and global output gaps as inflation drivers: What does the Phillips curve tell? BIS Working Papers, No. 748, Bank for International Settlements, Switzerland.

Lagoa, S. (2014). Determinants of inflation differentials in the Euro area: Is the New Keynesian Phillips curve enough? Journal of Applied Economics, 20(1), 75-103. doi:10.1016/S15140326(17)30004-1

Lepetit, A. (2018). Asymmetric unemployment fluctuations and monetary policy trade-offs. HAL Working Paper 01536416.

Mazumder, S. (2012). European inflation and the New Keynesian Phillips curve. Southern Economic Journal, 79(2), 322-349. doi:10.4284/0038-4038-2011.149

Moosa, I. A., 1997. A cross-country comparison of Okun's coefficient. Journal of Comparative Economics, 24(3), 335-356.

Morley, J., \& Panovska, I. B. (2019). Is business cycle asymmetry intrinsic in industrialized economies? Macroeconomic Dynamics, 1-34. doi:10.1017/S1365100518000913

Narodna banka Srbije (2018). Godišnji izveštaj o monetarnoj politici u 2018. godini. Beograd, RS: Narodna banka Srbije.

Oinonen, S., \& Paloviita, M. (2014). Updating the Euro area Phillips curve: The slope has increased. Research Discussion Paper No. 31/2014, Bank of Finland.

Orphanides, A., \& van Norden, S. (2005). The reliability of inflation forecasts based on output gap estimates in real time. Journal of Money, Credit and Banking, 37(3), 583-601.

Peneva, E. V., \& Rudd, J. B. (2017). The passthrough of labor costs to price inflation. Journal of Money, Credit and Banking, 49(8), 1777-1802. doi:10.1111/jmcb.12449

Pesaran, M. H., Shin, Y., \& Smith, R. J. (2001). Bounds testing approaches to the analysis of level relationships. Journal of Applied Econometrics, 16(3), 289-326. doi:10.1002/jae.616 
Petrović, P., Mladenović, Z., \& Nojković, A. (2011). Inflation triggers in transition economies: Their evolution and specific features. Emerging Markets Finance and Trade, 47(5), 101-124. doi:10.2753/REE1540-496X470505

Petrović, P., Brčerević D., \& Gligorić M. (2019). Why is Serbia an economic growth underachiever? Ekonomika preduzeća, 67(1-2), 17-32. doi:10.5937/ekopre1808017P

Posch, J., \& Rumler, F. (2014). Semi-structural forecasting of UK inflation based on the hybrid New Keynesian Phillips curve. Journal of Forecasting, 34(2), 145-162. doi:10.1002/ for.2319

Shin, Y., Yu, B., \& Greenwood-Nimmo, M. (2014). Modelling asymmetric cointegration and dynamic multipliers in anonlinear ARDL framework. In R. Sickles, \& W. Horrace (Eds.). Festschrift in honor of Peter Schmidt (pp. 281-314). Germany: Springer.

Toda, H. Y., \& Yamamoto, T. (1995). Statistical inference in vector autoregressions with possibly integrated processes. Journal of Econometrics, 66(1-2), 225-250. doi:10.1016/03044076(94)01616-8
Vašíček, B. (2011). Inflation dynamics and the New Keynesian Phillips curve in four Central European countries. Emerging Markets Finance and Trade, 47(5), 71-100. doi:10.2753/REE1540496X470504

Vasilev, A. (2015). New Keynesian Phillips curve estimation: The case of Hungary (1981-2006). Managing Global Transitions, 13(4), 355-367.

Wolde-Rufael, Y. (2005). Energy demand and economic growth: The African experience. Journal of Policy Modeling, 27(8), 891-903. doi:10.1016/j.jpolmod.2005.06.003

Xu, Q., Niu, X., Jiang, C., \& Huang, X. (2015). The Phillips curve in the US: A nonlinear quantile regression approach. Economic Modelling, 49(C), 186-197. doi:10.1016/j. econmod.2015.04.007

Zivot, E., \& Andrews, D. W. K. (1992). Further evidence on the great crash, the oil-price shock, and the unit-root hypothesis. Journal of Business \& Economic Statistics, 10(3), 251-270. doi:10.2307/1391541

Received on $6^{\text {th }}$ April 2020, after revision, accepted for publication on $17^{\text {th }}$ August 2020. Published online on $19^{\text {th }}$ August 2020.

Vladimir Mihajlovic is an Assistant Professor at the Faculty of Economics of the University of Kragujevac, the Republic of Serbia, where he obtained his PhD degree, in the scientific field: General Economics and Economic Development. The main areas of his scientific research are related to the development of economic thought, macroeconomic analysis and modelling, and labour market. 


\section{APPENDIX}

The graphical presentation of the tests for the dynamic stability of the New Keynesian Phillips curve models
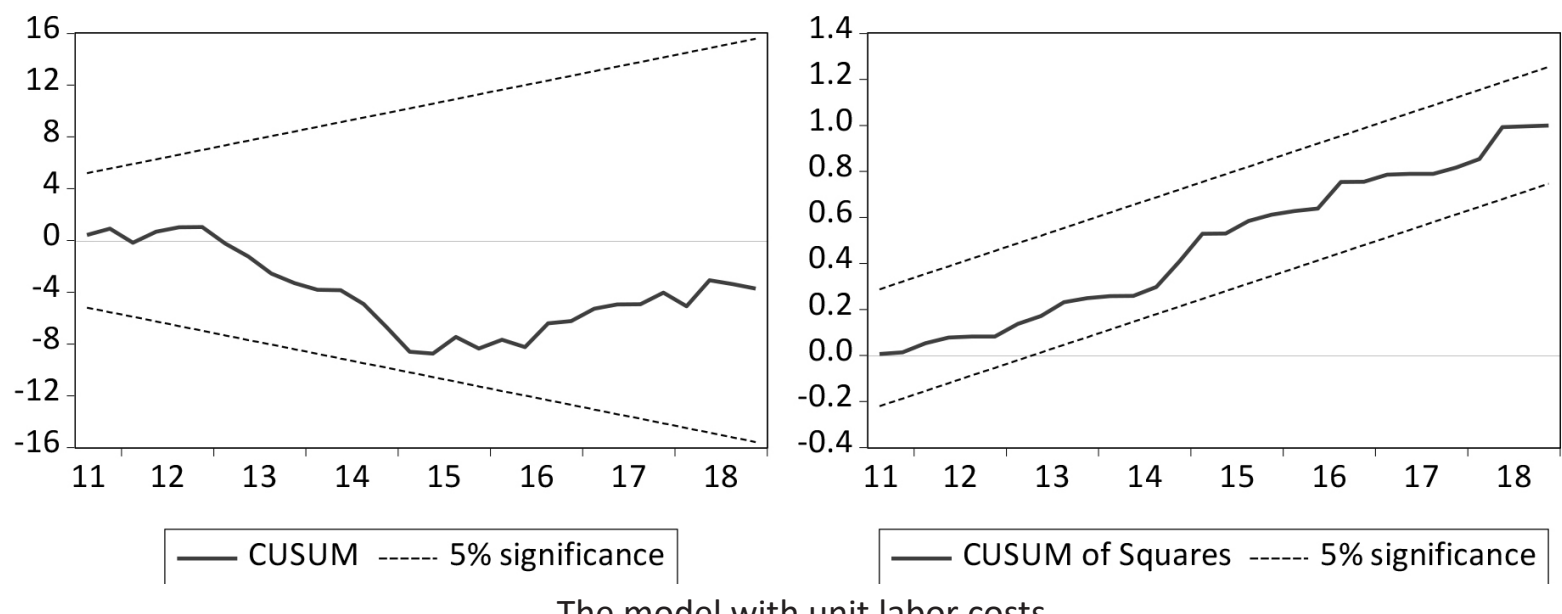

The model with unit labor costs
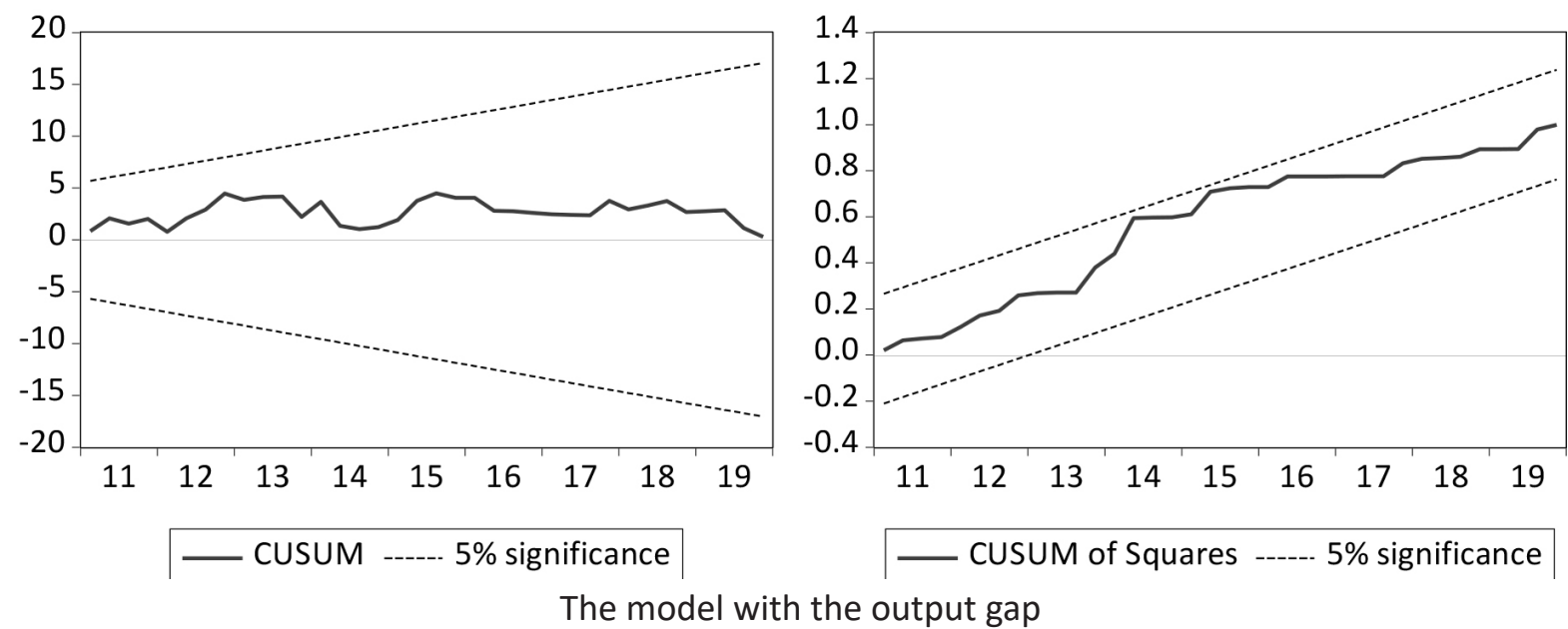

Source: Author 


\title{
NOVOKEJNZIJANSKA FILIPSOVA KRIVA I EFEKTI DOMAĆIH POKRETAČA INFLACIJE U REPUBLICI SRBIJI
}

\author{
Vladimir Mihajlović ${ }^{*}$ \\ Ekonomski fakultet Univerziteta u Kragujevcu
}

Istraživanje u radu odnosi se na ocenu validnosti novokejnzijanske Filipsove krive u kontekstu privrede Republike Srbije (RS). Empirijskom analizom kvantifikovan je uticaj domaćih pokretača na stopu inflacije - inflacionih očekivanja, realnih graničnih troškova i output gepa. Rezultati istraživanja ukazuju da inflacija u RS intenzivnije reaguje na negativne nego na pozitivne šokove ponude i tražnje, odnosno, značajnije opada tokom perioda kontrakcije privrede nego što raste tokom faze ekspanzije. Ocenjeni model novokejnzijanske Filipsove krive, u kojem figurišu granični troškovi, pruža nedvosmislene dokaze da se unapređenjem produktivnosti usporava rast troškovne inflacije kao komponente ukupne inflacije. Uticaj očekivane na stvarnu inflaciju je statistički značajan, iako u dinamici inflacije preovlađuje inerciona komponenta, to jest, efekat prošlih stopa inflacije na tekuću stopu. Empirijski nalazi o modelu Filipsove krive sa output gepom ukazuju da monetarna ekspanzija u RS, između ostalog, može da stimuliše privrednu aktivnost bez stvaranja značajnijih inflatornih pritisaka.

Ključne reči: stopa inflacije, output gep, jedinični troškovi rada, nelinearni ARDL model, dinamički multiplikator, asimetrija

JEL Classification: B22, C13, C32, E31

\section{UVOD}

Savremena empirijska analiza dinamike inflacije najčešće se bazira na novokejnzijanskom konceptu Filipsove krive. U izvornoj formi ove krive, predstavljen je uticaj domaćih pokretača inflacije $\mathrm{u}$ modelu zatvorene privrede. Stvarna inflacija je rezultat promena $\mathrm{u}$ očekivanoj budućoj inflaciji i faktorima realne ekonomske aktivnosti, kao što su

* Korespondencija: V. Mihajlović, Ekonomski fakultet Univerziteta u Kragujevcu, Liceja Kneževine Srbije 3, 34000 Kragujevac, Republika Srbija; e-mail: vmihajlovic@kg.ac.rs realni granični troškovi i odstupanje stvarne od potencijalne proizvodnje, odnosno, output gep. I pored rastuće međuzavisnosti nacionalnih ekonomija, u brojnim istraživanjima (Globan, Arčabić \& Sorić, 2015; Hałka \& Kotłowski, 2016; Abdih, Lin \& Paret, 2018) potvrđeno je da je dinamika inflacije i dalje, najvećim delom, rezultat uticaja domaćih pokretača kako u razvijenim, tako i u privredama sa nastajućim tržištem i tranzicionim ekonomijama. Rezultati studije Evropske centralne banke ukazuju da su u zemljama evrozone globalni faktori uticali na stopu inflacije samo tokom perioda 2008-2009, dok su u periodu 
2012-2015. preovladavali efekti domaćih pokretača inflacije (European Central Bank, 2017). U zemljama u tranziciji, uticaj domaćih pokretača inflacije je specifičan i često uslovljen karakterom i intenzitetom reformskih procesa na putu uspostavljanja tržišne privrede. Relativni značaj pojedinih pokretača inflacije varira tokom vremena, pri čemu dominirajući uticaj output gepa, fiskalnog deficita i političkih ciklusa, u inicijalnim fazama, smenjuje uticaj cena hrane i nafte, režima deviznog kursa i stanja tekućeg računa platnog bilansa u zrelijim fazama tranzicionog procesa (Petrović, Mladenović \& Nojković, 2011).

Republika Srbija (RS) je, u poređenju sa ostalim zemljama, $u$ proces tranzicionih reformi ušla relativno kasno. Kao i u drugim tranzicionim privredama, sprovođenje ovih reformi rezultiralo je visokim stopama inflacije $u$ početnim godinama. Tokom druge decenije XXI-og veka, unapređena je monetarna stabilnost i ublažena promenljivost stope inflacije, najvećim delom kao rezultat primene režima monetarne politike baziranog na ciljanju inflacije (Narodna banka Srbije, 2018). Međutim, dinamika domaćih pokretača inflacije u RS (output gep, obim agregatne tražnje, nivo produktivnosti, inflaciona očekivanja) $u$ navedenom periodu se karakterisala značajnim fluktuacijama. Budući da novokejnzijanski koncept Filipsove krive pretpostavlja snažnu vezu između ovih činilaca i stope inflacije, postavlja se pitanje $\mathrm{u}$ kojoj meri je pomenuti koncept validan $\mathrm{u}$ kontekstu privrede RS i kakav je egzaktan uticaj ovih pokretača na inflaciju.

$\mathrm{Ne}$ osporavajući uticaj eksternih činilaca dinamike inflacije (devizni kurs, udeo uvoza/ izvoza u BDP-u, cena nafte itd.), analiza u radu je usmerena na efekte domaćih faktora, budući da bolje razumevanje mehanizma i obima njihovog delovanja doprinosi dizajniranju efikasnijih mera monetarne politike posvećene očuvanju cenovne stabilnosti. Dodatni aspekt istraživanja odnosi se na ispitivanje nelinearnosti novokejnzijanske Filipsove krive u privredi RS. Naime, ova relacija bazira se na pretpostavci da su cene i nadnice, $u$ izvesnom stepenu, rigidne (nefleksibilne) u kratkom roku. Posledica njihove rigidnosti je asimetrično (nelinearno) prilagođavanje stope inflacije na promene u realnoj sferi privrede. Na primer, ako opšti nivo cena karakteriše rigidnost "na dole" (Downward Price Rigidity), može se očekivati da će privredna kontrakcija rezultirati kratkoročnim smanjenjem inflacije, koje je manjeg intenziteta od povećanja inflacije tokom perioda ekspanzije privrede. $U$ dugom roku cene su, po pretpostavci, fleksibilne, odnosno, nestaje uticaj ograničenja njihovom prilagođavanju, pa se može očekivati da će dugoročna reakcija stope inflacije na privredna kretanja biti simetrična.

Shodno navedenom, predmet istraživanja odnosi se na empirijsku analizu validnosti koncepta novokejnzijanske Filipsove krive i uloge domaćih pokretača inflacije u privredi RS.

Cilj istraživanja je da se utvrdi da li nezavisne varijable $u$ ovoj relaciji (očekivana stopa inflacije, realni granični troškovi i output gep) imaju značajan uticaj na stvarnu stopu inflacije. Pored toga, nastoji se da se ispita da li se stopa inflacije asimetrično prilagođava promenama ovih varijabli u dugom roku. Prisustvo asimetrije ima važne implikacije za monetarnu politiku, budući da intenzitet njenih mera treba da bude $\mathrm{u}$ skladu sa reakcijom inflacije $\mathrm{u}$ različitim fazama privrednog ciklusa.

Opredeljenje za tako postavljene predmet i cilj istraživanja motivisano je činjenicom da kvantifikovanje efekata domaćih pokretača pruža potpuniju sliku o uzrocima postojeće dinamike inflacije u RS tokom posmatranog perioda. Takođe, dodatni motiv istraživanja je u tome što, prema saznanjima autora, empirijske studije posvećene ispitivanju nelinearnosti novokejnzijanske Filipsove krive u privredi RS nisu rađene do sada, iako je ova relacija postala osnov savremene analize inflacije i stabilizacione politike.

U skladu sa postavljenim predmetom i ciljem istraživanja, testirane su sledeće istraživačke hipoteze:

H1: Očekivana buduća stopa inflacije ima statistički značajan uticaj na dinamiku stvarne stope inflacije u Republici Srbiji.

H2: Dinamika realnih graničnih troškova u privredi Republike Srbije ima pozitivan, statistički značajan i simetričan dugoročni uticaj na stopu inflacije. 
H3: Promene output gepa u periodima ekspanzije i kontrakcije privrede Republike Srbije su u pozitivnoj, statistički značajnoj i simetričnoj dugoročnoj vezi sa stopom inflacije.

Kao pogodan ekonometrijski pristup testiranju navedenih istraživačkih hipoteza, u radu se primenjuje nelinearni autoregresivni model raspoređenih docnji (Nonlinear Autoregressive Distributive Lag - NARDL), koji su razvili Y. Shin, B. Yu i M. Grenwood-Nimmo (2014). Ovaj pristup omogućava istovremenu analizu kratkoročnih i dugoročnih odnosa zavisne i nezavisnih varijabli i njihovih asimetričnih efekata. Dodatna prednost je u mogućnosti da se prikažu kumulativni efekti pokretača inflacije tokom vremena i uspostavljanje dugoročne ravnoteže nakon inicijalnog poremećaja izazvanog dejstvom šoka (Shin et al, 2014). Takođe, u kontekstu formulisanih istraživačkih hipoteza, ovim pristupom se sagledava ne samo smer i statistička značajnost veze između realnih graničnih troškova, output gepa i stope inflacije u RS, već i prisustvo dugoročne asimetrije $\mathrm{u}$ reakciji inflacije na promene navedenih varijabli tokom perioda ekspanzije i kontrakcije privrede.

Pored uvoda i zaključka, rad sadrži tri dela. U drugom delu, izložena je teorijska suština novokejnzijanske Filipsove krive i dat prikaz referentnih empirijskih istraživanja ove relacije. Treći deo se odnosi na predstavljanje korišćenog ekonometrijskog pristupa i podataka. Rezultati empirijskog istraživanja i diskusija obuhvaćeni su četvrtim delom rada.

\section{TEORIJSKA I EMPIRIJSKA OSNOVA NOVOKEJNZIJANSKE FILIPSOVE KRIVE}

\section{Teorijski okvir}

Novokejnzijanska Filipsova kriva predstavlja ishod konvergencije teorijskih koncepcija neoklasike i kejnzijanizma. Povezivanjem hipoteze racionalnih očekivanja, kao „zaštitnog znaka“ nove klasične makroekonomije, sa modelima rigidnosti cena i nadnica, novi kejnzijanci su načinili korak bliže uspostavljanju novog konsenzusa u makroekonomiji.
Upravo, modeliranje dinamike stope inflacije $u$ novom konsenzusu dominantno se zasniva na novokejnzijanskoj Filipsovoj krivoj (Galí, 2008). Tekuća stopa inflacije $\left(\pi_{t}\right)$ zavisi od tekućih očekivanja $u$ pogledu buduće stope inflacije $\left(E_{t} \pi_{(t+1)}\right)$, što je $u$ skladu sa hipotezom racionalnih očekivanja. Druga komponenta odražava uticaj promena $\mathrm{u}$ realnom sektoru na tekuću stopu inflacije, a u osnovnoj varijanti ove relacije odnosi se na dinamiku realnih graničnih troškova $\left(m c_{t}\right)$. Shodno tome, novokejnzijanska Filipsova kriva se može predstaviti izrazom (Galí, 2008):

$$
\pi_{t}=\beta E_{t}\left(\pi_{t+1}\right)+\lambda m c_{t^{\prime}}
$$

gde se $\beta$ odnosi na koeficijent uticaja očekivane buduće stope inflacije na tekuću stopu, dok $\lambda$ predstavlja funkciju učestalosti promene cena, a time i dinamike uticaja realnih graničnih troškova na stopu inflacije.

Promene graničnih troškova uslovljene su dinamikom produktivnosti i stepenom iskorišćenosti proizvodnih kapaciteta, kao i promenom cena proizvodnih input-a, koji mogu dovesti do troškovne inflacije. Osim ove verzije, zastupljena je i novokejnzijanska Filipsova kriva koja, umesto graničnih troškova, uključuje odstupanje stvarnog od potencijalnog output-a, odnosno, output gep. Naime, ako se pretpostavi da važi:

$$
m c=\kappa\left(y_{t}-y_{t}^{*}\right),
$$

odnosno, da se odnos graničnih troškova i output gepa $\left(y_{t}-y_{t}^{*}\right)$ može izraziti vrednošću parametra $\kappa$, sledi:

$$
\pi_{t}=\beta E_{t}\left(\pi_{t+1}\right)+\lambda \kappa\left(y_{t}-y_{t}^{*}\right)
$$

gde se $y_{t}$ i $y_{t}^{*}$ odnose na stvarni i potencijalni output, respektivno (Galí, 2008).

Pozitivni output gep nastaje u slučaju kada nivo agregatne tražnje $u$ privredi premaši potencijalnu ponudu, stvarajući inflatorni pritisak. Do negativnog output gepa dolazi u slučaju nedovoljne agregatne tražnje, vodeći smanjenju stope inflacije (Orphanides \& van Norden, 2005). 


\section{Pregled empirijskih istraživanja}

Budući da je istraživanjem $u$ radu obuhvaćena izvorna varijanta novokejnzijanske Filipsove krive za zatvorenu privredu, fokus ovog odeljka je na empirijske studije u kojim se ispituje uloga domaćih pokretača $u$ inflacionom procesu, kao i mogućnost asimetrije u njihovom uticaju na stopu inflacije.

Koristeći alternativne modele output gepa za privrede eurozone, S. Oinonen i M. Pallovita (2014) otkrivaju da je njegova vrednost bila negativna nakon 2012, što je dovelo do smanjenja stope inflacije ispod ciljane vrednosti i uzrokovalo povećanje nagiba Filipsove krive. C. Friedrich (2016) primenjuje faktorski model radi ocene parametara Filipsove krive u 25 razvijenih zemalja. Zaključuje da, pored output gepa, uključivanje inflacionih očekivanja u ovu relaciju doprinosi boljem predstavljanju dinamike inflacije. Analizirajući novokejnzijansku Filipsovu krivu u SAD, Q. Xu, X. Niu, C. Jiang i X. Huang (2015) pokazuju da povećanje output gepa dovodi do više i promenljivije stope inflacije. M. Jarociński i M. Lenza (2018) procenjuju uticaj output gepa na dinamiku inflacije u zemljama eurozone. Zaključuju, između ostalog, da povećanje agregatne tražnje može da smanji output gep bez povećanja inflacije. M. Jašová, R. Moessner i E. Takáts (2018) istražuju uticaj domaćih output gepova na inflaciju na panelu od 25 razvijenih zemalja i 22 privrede sa tržištima u nastajanju. Poredeći ih sa efektima globalnog output gepa, zaključuju da u oba slučaja prestavljaju značajne pokretače stope inflacije kako u periodu pre Velike recesije nastale 2008, tako i u post-kriznom periodu.

Dok empirijske studije, uglavnom, potvrđuju da je output gep značajna odrednica dinamike stope inflacije, rezultati studija koje analiziraju varijantu novokejnzijanske Filipsove krive sa graničnim troškovima nisu ni približno unisoni, a rezultati zavise od izbora privrede koja se analizira. Na primer, S. Lagoa (2014) dokazuje da se promenama nominalnih jediničnih troškova rada i odnosom između cena i troškova u dugom roku mogu objasniti razlike u stopi inflacije u privredama eurozone. J. Posh i F. Rumler (2014) ocenjuju model hibridne novokejnzijanske
Filipsove krive sa graničnim troškovima u slučaju otvorene privrede. Njihov model dobro odražava promene inflacije u Velikoj Britaniji, ali samo $\mathrm{u}$ kratkom roku. Nasuprot tome, S. Mazumder (2012) pokazuje da realni jedinični troškovi rada ne mogu da objasne dinamiku inflacije $\mathrm{u}$ evropskim privredama i da loše aproksimiraju promene realnih graničnih troškova. Do sličnih zaključaka za SAD dolaze E. V. Peneva i J. B. Rudd (2017). Navedene kontroverze otvaraju prostor za dodatna istraživanja i primenu drugačije metodologije kako bi se došlo do validnijih i nedvosmislenih zaključaka o uticaju ovih troškova na stopu inflacije.

Nasuprot istraživanjima koja se odnose na privrede razvijenih zemalja, studije koje analiziraju novokejnzijansku Filipsovu krivu u (bivšim) tranzicionim privredama, uglavnom, ističu da je značaj inflacionih očekivanja i realnih graničnih troškova ograničen, kao i da je prisutan viši stepen rigidnosti cena. Tako, A. Dabušinskas i D. Kulikov (2007) razvijaju model Filipsove krive za Baltičke ekonomije (Estonija, Letonija i Litvanija) i zaključuju da je tekuća inflacija determinisana prethodnim stopama, manjim delom očekivanom budućom inflacijom, dok uticaj realnih graničnih troškova nije značajan. Do sličnih rezultata dolaze B. Vašíček (2011) za Višegradsku grupu zemalja, A. Vasilev (2015) za Mađarsku i F. Furuoka (2016) za Baltičke privrede. Nasuprot tome, istražujući validnost novokejnzijanske Filipsove krive u Češkoj, M. Bouda (2013) pronalazi dokaze da očekivana stopa inflacije, uz šokove monetarne politike, ima ključan uticaj na tekuću stopu. M. Basarac, B. Škrabić i P. Sorić (2011) analiziraju hibridnu Filipsovu krivu u devet tranzicionih privreda i otkrivaju statistički značajnu dugoročnu vezu između tekuće inflacije, očekivane inflacije i output gepa.

Poslednjih godina, sve više empirijskih studija se orijentiše na ispitivanje nelinearnosti (asimetrije) $u$ odnosu nezavisnih varijabli Filipsove krive i stope inflacije. Na primer, P. G. Egan i A. J. Leddin (2017) ispituju dinamiku inflacijeu Kinii zaključuju da je veza između inflacije i output-a nelinearna. Analizirajući fluktuacije nezaposlenosti u novokejnzijanskom 
modelu, A. Lepetit (2018) procenjuje ulogu asimetrije na tržištu rada $u$ dizajniranju efikasne monetarne politike. Zaključuje da ova asimetrija predstavlja ključnu odrednicu odnosa inflacije i nezaposlenosti, kao i da monetarnom politikom treba delovati ne samo na inflaciju, već i na nezaposlenost. Primenom NARDL modela, u kombinaciji sa metodima uzročnosti, M. E. Bildirici i F. Özaksoy Sonustun (2018) ispituju odnos između inflacije i nezaposlenosti u Japanu, Turskoj, SAD i Francuskoj. Rezultati empirijske analize ukazuju na prisustvo negativne i asimetrične veze između ovih veličina u dugom roku. J. Morley i I. B. Panovska (2019) istražuju asimetričnost privrednih ciklusa u deset razvijenih ekonomija. Otkrivaju da se output gep značajnije menja u periodima recesije nego ekspanzije, što upućuje na zaključak da je Filipsova kriva, uglavnom, konveksna. Istraživanje S. Ho i B. N. Iyke (2019) potvrđuje nelinearnost Filipsove krive u jedanaest zemalja eurozone i ukazuje da je njen nagib negativan kada je stopa nezaposlenosti niža od 5\%.

Imajući $u$ vidu postojeće empirijske studije, istraživanje $u$ ovom radu popunjava jaz $u$ literaturi o ulozi i značaju asimetričnih efekata $u$ novokejnzijanskoj Filipsovoj krivoj u tranzicionim privredama, fokusirajući se na privredu RS. Rezultati empirijske analize mogu da unaprede razumevanje inflacionog procesa i posluže nosiocima monetarne politike u svrhu dizajniranja efikasnijih mera za postizanje i očuvanje monetarne stabilnosti.

\section{METODOLOGIJA ISTRAŽIVANJA I PODACI}

\section{Ekonometrijski model}

Osnovni problem u empirijskoj analizi validnosti Filipsove krive, date izrazom (1), ogleda se u činjenici da podaci o dinamici realnih graničnih troškova najčešće nisu raspoloživi. Shodno tome, J. Galí i M. Gertler (1999) su predložili da se kao adekvatna aproksimacija koriste jedinični troškovi rada, što je primenjeno $\mathrm{u}$ brojnim empirijskim istraživanjima (Furuoka, 2016; Peneva \& Rudd, 2017; Chin, 2018). Naime, ovi autori aproksimiraju realni granični trošak prosečnim troškom rada i definišu ga kao udeo sume nadnica u nominalnom output-u, odnosno:

$$
m c_{t}=\frac{w_{t} n_{t}}{p_{t} y_{t}}
$$

gde je $w_{t}$ nominalna nadnica, $n_{t}$ označava zaposlenost, $p_{t}$ je nivo cena i $y_{t}$ predstavlja output.

Udeo sume nadnica $\mathrm{u}$ nominalnom output-u može se suštinski posmatrati kao realni jedinični trošak rada $\left(\varphi_{t}\right)$, što opravdava njegovo uključivanje u model umesto realnog graničnog troška. Takođe, za potrebe empirijske analize u ovom radu, relacija (1) se može dopuniti dodavanjem odsečka $\left(\alpha_{0}\right)$, koji pokazuje stopu inflacije kada su vrednosti ostalih veličina desno od znaka jednakosti jednake nuli, i parametra koji se odnosi na slučajnu grešku $\left(\varepsilon_{t}\right)$, tako da dobije oblik:

$$
\pi_{t}=\alpha_{0}+\beta_{1} \pi_{t}^{e}+v \varphi_{t}+\varepsilon_{t^{\prime}}
$$

gde $\pi_{t}^{e}$ označava očekivanu buduću inflaciju, dok koeficijent $v$ meri efekat promene jediničnih troškova rada na stopu inflacije.

Na isti način se može preurediti izraz (3), u kojem figuriše output gep, tako da model novokejnzijanske Filipsove krive, koji se empirijski ocenjuje, ima sledeću formu:

$$
\pi_{t}=\alpha_{1}+\beta_{2} \pi_{t}^{e}+\gamma x_{t}+\varepsilon_{t^{\prime}}
$$

gde $x_{t}$ označava output gep $\left(x_{t} \equiv y_{t}-y_{t}^{*}\right)$.

Empirijska analiza odnosa između navedenih varijabli $\mathrm{u}$ ovom radu zasniva se na primeni nelinearne forme autoregresivnog modela raspoređenih docnji. Budući da se kao regresori uključuju vrednosti zavisne i nezavisnih varijabli sa određenim vremenskim pomacima (docnjama), ovim modelom se bolje obuhvata dinamika njihovih odnosa i izbegava problem sa autokorelacijom reziduala (Moosa, 1997).

Polazeći od relacije (5), Autoregressive Distributed Lag (ARDL) model $(m, n)$ novokejnzijanske Filipsove krive može se izraziti u obliku: 


$$
\begin{gathered}
\Delta \pi_{t}=\alpha_{0}+\beta_{1} \pi_{t-1}+\delta_{1} \pi_{t-1}^{e}+v \varphi_{t-1}+ \\
\sum_{j=1}^{m} \vartheta_{j} \Delta \pi_{t-j}+\sum_{j=0}^{n} \tau_{j} \Delta \varphi_{t-j}+\varepsilon_{t}
\end{gathered}
$$

gde $\Delta$ označava prvu diferencu, $\beta_{1}, \delta_{1}$ i $v$ predstavljaju dugoročne koeficijente, $\vartheta$ i $\tau$ su kratkoročni koeficijenti, dok $m$ i $n$ označavaju broj vremenskih pomaka.

Može se uočiti da se očekivana stopa inflacije $\left(\pi^{e}\right)$ tretira kao fiksni regresor, bez rasporeda docnji koji bi se odnosio na odnos sa tekućom inflacijom u kratkom roku. Na taj način se modelira dugoročni odnos između stvarne stope inflacije u posmatranom kvartalu i očekivane stope inflacije za isti kvartal naredne godine, budući da su tako strukturirani podaci koji se koriste za istraživanje.

Za potrebe testiranja druge istraživačke hipoteze, neophodno je dekomponovati dinamiku jediničnih troškova rada $\left(\varphi_{t}\right)$ na pozitivne i negativne promene i utvrditi njihov uticaj na stopu inflacije. Promene ovih troškova su razdvojene $u$ rastuće i opadajuće parcijalne sume, to jest, $\varphi_{t}=\varphi+\varphi_{t}^{+}+\varphi_{t}^{-}$, gde $\varphi_{t}^{+}$ i $\varphi_{t}^{-}$predstavljaju parcijalne sume pozitivnih i negativnih promena realnih jediničnih troškova rada, respektivno, kao što sledi (Shin et al, 2014):

$$
\begin{aligned}
& \varphi_{t}^{+}=\sum_{j=0}^{t} \Delta \varphi_{j}^{+}=\sum_{j=0}^{t} \max \left(\Delta \varphi_{j}, 0\right) \\
& \varphi_{t}^{-}=\sum_{j=0}^{t} \Delta \varphi_{j}^{-}=\sum_{j=0}^{t} \min \left(\Delta \varphi_{j}, 0\right)
\end{aligned}
$$

Zamenom varijable $\varphi_{t} \mathrm{u}$ modelu (7) varijablama $\varphi_{t}^{+} \mathrm{i}$ $\varphi_{t}$, dobija se NARDL model, $\mathrm{u}$ formi:

$$
\begin{aligned}
& \Delta \pi_{t}=\alpha_{0}+\beta_{1} \pi_{t-1}+\delta_{1} \pi_{t-1}^{e}+v^{+} \varphi_{t-1}^{+}+v^{-} \varphi_{t-1}^{-}+ \\
& \sum_{j=1}^{m} \vartheta_{j} \Delta \pi_{t-j}+\sum_{j=0}^{n}\left(\tau_{j}^{+} \Delta \varphi_{t-j}^{+}+\tau_{j}^{-} \Delta \varphi_{t-j}^{-}\right)+\varepsilon_{t}
\end{aligned}
$$

Primenjujući identičan postupak, polazeći od relacije (6), novokejnzijanska Filipsova kriva u obliku ARDL $(p, q)$ modela se može izraziti na sledeći način:

$$
\begin{aligned}
& \Delta \pi_{t}=\alpha_{1}+\beta_{2} \pi_{t-1}+\delta_{2} \pi_{t-1}^{e}+\gamma x_{t-1}+ \\
& \sum_{i=1}^{p} \kappa_{i} \Delta \pi_{t-i}+\sum_{i=0}^{q} \mu_{i} \Delta x_{t-i}+\varepsilon_{t}
\end{aligned}
$$

gde su $\beta_{2^{\prime}} \delta_{2} \mathrm{i} \gamma$ dugoročni koeficijenti, $\kappa \mathrm{i} \mu$ označavaju kratkoročne koeficijente, dok $p$ i $q$ predstavljaju brojeve docnji.

Promene u output gepu $\left(\mathrm{x}_{t}\right)$ su dekomponovane na rastuće $\left(\mathrm{x}_{t}^{+}\right)$i opadajuće $\left(\mathrm{x}_{t}^{-}\right)$parcijalne sume na sledeći način:

$$
\begin{aligned}
& x_{t}^{+}=\sum_{i=0}^{t} \Delta x_{i}^{+}=\sum_{i=0}^{t} \max \left(\Delta x_{i}, 0\right) \\
& x_{t}^{-}=\sum_{i=0}^{t} \Delta x_{i}^{-}=\sum_{i=0}^{t} \min \left(\Delta x_{i}, 0\right)
\end{aligned}
$$

NARDL model novokejnzijanske Filipsove krive sa output gepom, kojim se testira treća istraživačka hipoteza, dobija se zamenom $x_{t}$ varijablama $x_{t}^{+}$i $x_{t}^{-} \mathrm{u}$ relaciji (10):

$$
\begin{aligned}
& \Delta \pi_{t}=\alpha_{1}+\beta_{2} \pi_{t-1}+\delta_{2} \pi_{t-1}^{e}+ \\
& \gamma^{+} x_{t-1}^{+}+\gamma^{-} x_{t-1}^{-}+\sum_{i=1}^{p} \kappa_{i} \Delta \pi_{t-i}+ \\
& \sum_{i=0}^{q}\left(\mu_{i}^{+} \Delta x_{t-i}^{+}+\mu_{i}^{-} \Delta x_{t-i}^{-}\right)+\varepsilon_{t}
\end{aligned}
$$

Za ispitivanje prisustva dugoročnih veza (kointegracije) između stope inflacije i objašnjavajućih varijabli, korišćen je tzv. test kritičnih graničnih vrednosti (Bounds test), koji su razvili M. H. Pesaran, Y. Smit i R. J. Shin (2001). Testirana je nulta hipoteza da su vrednosti dugoročnih koeficijenata jednake nuli (odsustvo kointegracije), odnosno, $\mathrm{H}_{0}: \beta_{1}=\delta_{1}=v^{+}=v^{-}=0$ (jednačina 9) i $\mathrm{H}_{0}: \beta_{2}=\delta_{2}=\gamma^{+}=\gamma^{-}=0$ (jednačina 12).

Prisustvo dugoročne asimetrije je ispitano testiranjem nulte hipoteze o jednakosti dugoročnih koeficijenata pozitivnih i negativnih promena jediničnih troškova rada, to jest, $H_{0}: L_{\varphi}^{+}=L_{\varphi}^{-}\left(\right.$gde je $\left.L_{\varphi}^{+}=-v^{+} / \beta_{1} i L_{\varphi}^{-}=-v^{-} / \beta_{1}\right)$, kao i pozitivnih i negativnih promena output gepa, $\mathrm{H}_{0}$ : $L_{x}^{+}=L_{x}^{-}\left(\right.$gde je $L_{x}^{+}=-\gamma^{+} / \beta_{2}$ i $\left.L_{x}^{-}=-\gamma^{-} / \beta_{2}\right)$. Odbacivanje nultih hipoteza pri datom nivou statističke značajnosti, ukazuje da postoji dugoročni asimetrični odnos između stope inflacije i navedenih regresora.

Prisustvo kratkoročnog asimetričnog odnosa pomenutih varijabli ispitano je testiranjem nulte hipoteze o odsustvu asimetrije u relacijama (9) i (12), odnosno, $\mathrm{H}_{0}: \sum_{j=0}^{n} \tau_{j}^{+}=\sum_{j=0}^{n} \tau_{j}^{-}$i $\mathrm{H}_{0}: \sum_{i=0}^{q} \mu_{i}^{+}=\sum_{i=0}^{q} \mu_{i}^{-}$, respektivno. Za testiranje svih hipoteza, primenjen je Wald test, kao u slučaju brojnih empirijskih istraživanja (Shin et al, 2014; Bildirici \& Özaksoy, 2018). 
Da bi se prikazao kumulativni uticaj promena nezavisnih varijabli na stopu inflacije od kratkog ka dugom roku, korišćeni su, takozvani, dinamički multiplikatori (Shin et al, 2014). Oni pokazuju efekte povećanja i smanjenja za $1 \%$ jediničnih troškova rada i output gepa na stopu inflacije.

\section{Podaci}

Za empirijsko istraživanje su korišćene vremenske serije kvartalnih podataka o međugodišnjoj stvarnoj i očekivanoj stopi inflacije (12 meseci unapred, anketa sektora privrede), realnim indeksima jediničnih troškova rada (u industriji) i realnom bruto domaćem proizvodu (BDP). Podaci su prikupljeni iz baza Narodne banke Srbije i Eurostat-a. Analizom je obuhvaćen period od prvog kvartala 2008. do

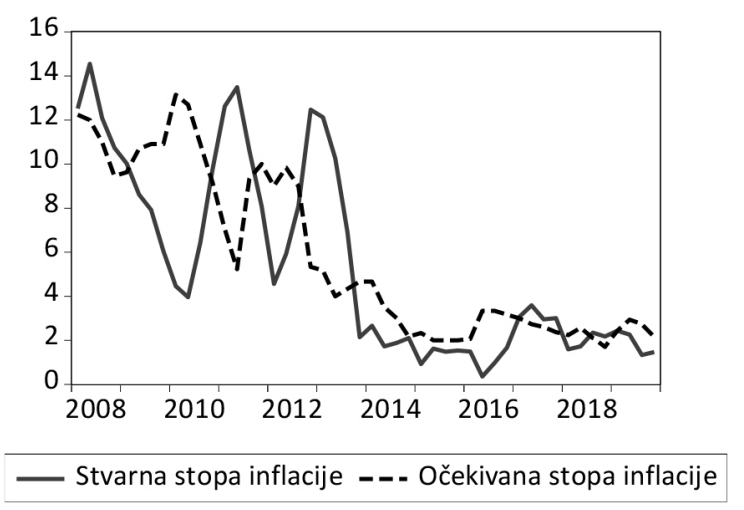

četvrtog kvartala 2019, (48 opservacija). Budući da se dinamika stope inflacije, inflacionih očekivanja i indeksa jediničnih troškova rada prati na mesečnoj bazi, primenjena je konverzija na kvartalne podatke, primenom metode prosečnih opservacija. Output gep je izračunat dekomponovanjem serije kvartalnih podataka o realnom BDP-u na cikličnu i komponentu trenda, primenom Hodrik-Preskot $(\mathrm{HP})$ filtera $(\lambda=$ 1600).

Dinamika analiziranih varijabli $u$ RS tokom posmatranog perioda predstavljena je na Slici 1 . Uočava se da očekivana i stvarna stopa inflacije slede relativno sličan obrazac kretanja, a da se nakon 2014. njihove vrednosti značajno približavaju. To može biti inicijalni signal o statistički značajnoj vezi između ovih veličina. Takođe, period nakon 2014. karakteriše evidentan pozitivan odnos između output gepa i stope
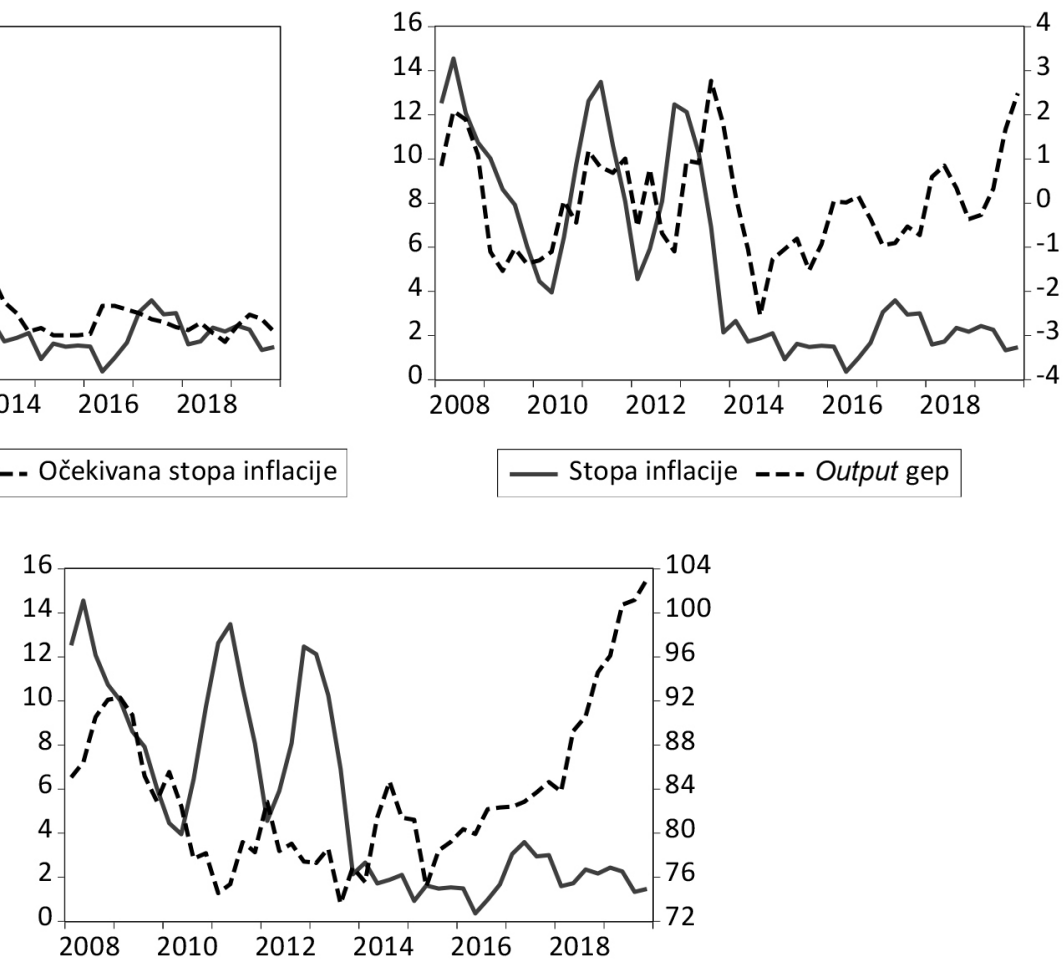

Stopa inflacije - -- Realni jedinični troškovi rada (2019=100)

Slika 1 Dinamika analiziranih varijabli u Republici Srbiji

Izvor: Autor, na osnovu podataka Narodne banke Srbije 
inflacije, dok tačan smer veze između jediničnih troškova rada i stope inflacije nije vizuelno uočljiv. Preliminarna analiza relacija posmatranih varijabli, putem dijagrama raspršenosti (Slika 2), ukazuje da postoji pozitivna veza između stope inflacije i svih nezavisnih varijabli, osim jediničnih troškova rada, koji su negativno korelisani sa stopom inflacije. Naravno, to nužno ne upućuje na finalne rezultate analize, budući da je dinamika nezavisnih varijabli dekomponovana na pozitivne i negativne promene, koje zatim služe kao odvojeni regresori.

\section{REZULTATI ISTRAŽIVANJA I DISKUSIJA}

Budući da je za validnu primenu nelinearnog ARDL modela neophodno da sve varijable budu stacionarne $\mathrm{u}$ nivou $\mathrm{i} / \mathrm{ili} \mathrm{u}$ prvoj diferenci, najpre je potrebno primeniti različite testove jediničnog korena na posmatrane vremenske serije. Rezultati parametarskog Augmented Dickey-Fuller (ADF) i neparametarskog Phillips-Perron (PP) testa, dati u Tabeli 1, potvrđuju da je ovaj uslov ispunjen. Primenjen je i Zivot-Andrews test (Zivot \& Andrews, 1992), kojim se uzima u obzir prisustvo strukturnih prekida i time dolazi do robustnijih rezultata. Ovaj test potvrđuje prethodne rezultate, odnosno, nijedna od posmatranih varijabli nije reda integrisanosti I(2). Navedenim testom su određeni i kvartali u kojima je došlo do strukturnog prekida u vremenskim serijama i na bazi kojih su kreirane veštačke promenljive. One uzimaju vrednost 0 do datuma prekida, a vrednost 1 nakon tog datuma.

Pre ocene parametara finalnog NARDL modela, neophodno je proveriti smer kauzalnosti između analiziranih varijabli. Sve verzije Filipsove krive, uključujući i novokejnzijansku, polaze od stope inflacije kao zavisne varijable. Shodno tome, primenjen je Grejndžerov test ne-kauzalnosti kako bi se utvrdilo da li se prošlim promenama $u$ jediničnim troškovima rada i output gepu mogu objasniti promene u stopi inflacije. Ovaj test je sproveden primenjujući Toda-Yamamoto proceduru (Toda \& Yamamoto, 1995), budući da su testovi jediničnih korena pokazali da su vremenske serije različitog reda integrisanosti (I(0) i/ili I(1)). Navedenom procedurom se ispituje kauzalnost između vremenskih serija $u$ nivoima, čime se smanjuje rizik pogrešne procene njihove stacionarnosti (Wolde-Rufael, 2005). Takođe, ispitan je i smer uzročnosti između serija pozitivnih i negativnih promena jediničnih troškova rada, odnosno, output gepa, i stope inflacije, na način koji sugeriše A. Hatemi-J (2012).

Rezultati testa uzročnosti dati su u Tabeli 2 i potvrđuju da je prisutan smer uzročnosti od realnih graničnih troškova i output gepa ka stvarnoj stopi inflacije. Pored toga, pozitivne i negativne promene $\mathrm{u}$ ovim veličinama takođe predstavljaju odrednicu budućeg kretanja stope inflacije. Isto važi i za očekivanu stopu
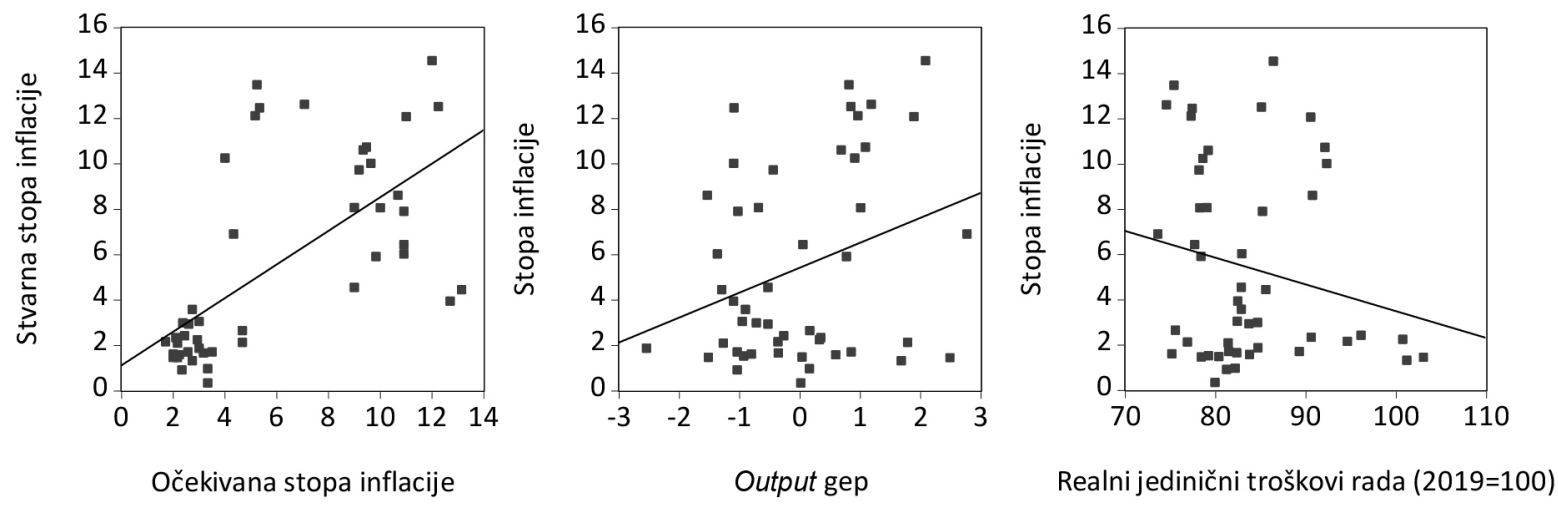

Slika 2 Dijagrami raspršenosti odnosa stope inflacije i nezavisnih varijabli 
Tabela 1 Rezultati testova stacionarnosti

\begin{tabular}{c|cc|cc|cc}
\hline \multirow{2}{*}{ Varijabla } & \multicolumn{2}{|c|}{ ADF test } & \multicolumn{2}{c|}{ PP test } & \multicolumn{2}{c}{ Zivot-Adrews test } \\
& Konstanta & $\begin{array}{c}\text { Konstanta i } \\
\text { trend }\end{array}$ & Konstanta & $\begin{array}{c}\text { Konstanta i } \\
\text { trend }\end{array}$ & t-statistika & $\begin{array}{c}\text { Strukturni } \\
\text { prekid }\end{array}$ \\
\hline$\pi$ & $-1,66$ & $-2,57$ & $-1,88$ & $-2,49$ & $-4,64^{* * *}$ & $2014 \mathrm{Q} 2$ \\
$\pi^{e}$ & $-1,28$ & $-2,21$ & $-1,56$ & $-2,21$ & $-4,95^{* * *}$ & $2012 \mathrm{Q} 4$ \\
$x$ & $-2,88^{*}$ & $-2,84$ & $-2,97^{* *}$ & $-3,01$ & $-3,95^{* * *}$ & $2014 \mathrm{Q} 2$ \\
$\varphi$ & $-1,17$ & $-0,99$ & $-1,17$ & $-0,87$ & $-2,69^{*}$ & $2010 \mathrm{Q} 2$ \\
$\Delta \pi$ & $-2,80^{*}$ & $-2,81$ & $-3,99^{* * *}$ & $-4,02^{* *}$ & $-3,59^{* * *}$ & $2013 \mathrm{Q} 1$ \\
$\Delta \pi^{e}$ & $-5,95^{* * *}$ & $-6,08^{* * *}$ & $-5,76^{* * *}$ & $-5,73^{* * *}$ & $-6,81$ & $2013 \mathrm{Q} 3$ \\
$\Delta x$ & $-5,66^{* * *}$ & $-5,47^{* * *}$ & $-6,69^{* * *}$ & $-6,74^{* * *}$ & $-6,12^{*}$ & $2013 \mathrm{Q} 4$ \\
$\Delta \varphi$ & $-6,94^{* * *}$ & $-7,31^{* * *}$ & $-6,93^{* * *}$ & $-7,81^{* * *}$ & $-4,83^{* *}$ & $2015 \mathrm{Q} 2$ \\
\hline
\end{tabular}

Napomena: Rezultati označeni simbolima * ** ${ }_{i} * * *$ su statistički značajni na nivou $10 \%, 5 \%$ i 1\%, respektivno.

Izvor: Autor

inflacije. Shodno tome, smer uzročnosti posmatranih varijabli koje se odnose na privredu RS su u skladu sa novokejnzijanskom Filipsovom krivom.

Finalna specifikacija NARDL modela za obe varijante novokejnzijanske Filipsove krive, predstavljena je $\mathrm{u}$ Tabeli 3. Do nje se došlo sukcesivnim uklanjanjem vremenskih pomaka koji nisu statistički značajni, počev od 4 inicijalna pomaka. Testovi reziduala (normalnosti, autokorelacije, heteroskedastičnosti, dinamičke stabilnosti i funkcionalne forme), pokazuju da su oba modela dobro specificirana i stabilna. Rezultati testa kointegracije (FPSS), prikazani u poslednjem redu Tabele 3, potvrđuju da između zavisne i nezavisnih varijabli $u$ oba modela postoji dugoročna veza. Očekivana buduća inflacija ima statistički značajan uticaj na stvarnu stopu inflacije $u$ oba modela. Uočava se i da je, u prvom modelu, vrednost koeficijenta dugoročnog uticaja negativnih promena jediničnih troškova rada na inflaciju $\left(L_{\varphi}{ }^{-}\right)$statistički značajna i veća od vrednosti

Tabela 2 Rezultati Grejndžerovog testa ne-kauzalnosti (Toda-Yamamoto procedura)

\begin{tabular}{cc|cc|cc}
\hline \multicolumn{2}{c|}{ Simetrični pristup } & \multicolumn{2}{c|}{$\begin{array}{c}\text { Asimetrični pristup - pozitivne } \\
\text { promene egzogenih varijabli }\end{array}$} & \multicolumn{2}{c}{$\begin{array}{c}\text { Asimetrični pristup - negativne } \\
\text { promene egzogenih varijabli }\end{array}$} \\
\hline$H_{0}$ & $\chi^{2}$ & $H_{0}$ & $\chi^{2}$ & $H_{0}$ & $\chi^{2}$ \\
$\varphi \rightarrow \pi$ & $7,57^{*}$ & $\varphi^{+} \rightarrow \pi$ & $8,06^{*}$ & $\varphi+\pi$ & $5,89^{*}$ \\
$\pi \rightarrow \varphi$ & 1,20 & $\pi \rightarrow \varphi^{+}$ & 1,29 & $\pi \rightarrow \varphi$ & 3,85 \\
$x \rightarrow \pi$ & $2,81^{*}$ & $x^{+}+\pi$ & 6,09 & $x \rightarrow \pi$ & $5,91^{*}$ \\
$\pi \rightarrow x$ & 1,12 & $\pi \rightarrow x^{+}$ & 3,52 & $\pi \rightarrow x$ & 1,96 \\
$\pi^{e} \rightarrow \pi$ & $6,40^{* *}$ & - & - & - & - \\
$\pi \rightarrow \pi^{e}$ & 2,13 & - & - & - & - \\
\hline
\end{tabular}

Napomene: Simbol $\nrightarrow \rightarrow$ znači „,ne uzrokuje u smislu Grejndžera“; rezultati označeni simbolima *, ** $\mathrm{i}$ *** su statistički značajni na nivou $10 \%, 5 \%$ i $1 \%$, respektivno.

Izvor: Autor 
koeficijenta pozitivnih promena $\left(L_{\varphi}^{+}\right)$. Tačnije, povećanje jediničnih troškova rada za $1 \%$ povećava stopu inflacije za $0,28 \%$, dok njihovo smanjenje za $1 \%$ vodi padu inflacije za $0,61 \%$. Rezultati Wald testa $\left(W_{L R}\right)$ potvrđuju da je odnos između promena jediničnih troškova rada i stope inflacije asimetričan u dugom roku. Budući da je dinamika navedenih troškova uslovljena promenom nivoa produktivnosti, ovaj nalaz ukazuje da bi unapređenje produktivnosti moglo da dovede do usporavanja troškovne inflacije kao komponente ukupne inflacije u RS.

$\mathrm{U}$ drugom modelu, promene output gepa, u oba smera, statistički značajno utiču na inflaciju, pri čemu je vrednost koeficijenta negativnih promena output gepa $\left(L_{x}^{-}\right)$veća od koeficijenta pozitivnih promena $\left(L_{x}^{+}\right)$: smanjenje vrednosti output gepa za $1 \%$ vodi padu inflacije za 1,28\%, dok povećanje njegove vrednosti za $1 \%$ izaziva porast stope inflacije za 1,09\%. Međutim, rezultat Wald testa pokazuje da između vrednosti ova dva koeficijenta ne postoji statistički značajna razlika, odnosno, da je odnos output gepa i inflacije u dugom roku simetričan.

Ukoliko se prihvati da jedinični troškovi rada predstavljaju dobru aproksimaciju za granične troškove, može se konstatovati da su dobijeni rezultati o dugoročnom odnosu u posmatranim varijantama Filipsove krive konzistentni, budući da negativne promene output gepa (u periodu kontrakcije privrede) korespondiraju sa redukcijom graničnih troškova, zbog smanjenja stepena iskorišćenosti proizvodnih kapaciteta. Dakle, granični troškovi beleže prociklično kretanje, što je dokazano u brojnim empirijskim studijama (Alexová, 2012; Vasilev, 2015; Furuoka, 2016).

Kada je u pitanju kratkoročna asimetrija, Wald test $\left(\mathrm{W}_{\mathrm{SR}}\right)$ pokazuje da je odnos između output gepa i stope inflacije asimetričan u kratkom roku, što nije slučaj kod modela sa jediničnim troškovima rada. Asimetrija u odnosu između output gepa i inflacije u kratkom roku je posledica nesrazmernog prilagođavanja inflacije tokom perioda ekspanzije i kontrakcije privrede usled prisustva određenog stepena rigidnosti cena, što je $u$ skladu sa konceptom novokejnzijanske Filipsove krive.
Kumulativni uticaj domaćih pokretača inflacije u RS, kao i tendenciju uspostavljanja dugoročne ravnoteže nakon inicijalnog poremećaja (šoka), moguće je pratiti putem dinamičkih multiplikatora (Shin et al, 2014). Slika 3a predstavlja efekte povećanja i smanjenja jediničnih troškova rada na stopu inflacije tokom vremena. Negativne promene ovih troškova (isprekidana siva linija) dovode do smanjenja stope inflacije, koje je izraženije kratkoročno (aproksimativno tokom 5 kvartala nakon inicijalnog šoka), a zatim se taj uticaj smanjuje ka dugom roku. Pozitivne promene jediničnih troškova rada (puna siva linija) inicijalno dovode do smanjenja stope inflacije, a zatim do povećanja u dugom roku. Isprekidana crna linija predstavlja razliku između efekata pozitivnih i negativnih promena na stopu inflacije, odnosno, asimetriju. Prikazana je zajedno sa pratećim linijama, koje označavaju donju i gornju granicu intervala poverenja od 95\%. Ukoliko se nulta linija nađe $\mathrm{u}$ okviru intervala poverenja, to je pokazatelj da nema asimetrije. Sa Slike 3a se uočava da postoji dugoročna asimetrija, ali ne i kratkoročna, što je u skladu sa rezultatima Wald testa u Tabeli 3. Dugoročna ravnoteža se ostvaruje aproksimativno 10 kvartala nakon inicijalne promene jediničnih troškova rada.

Uticaj promena u output gepu na stopu inflacije od kratkog ka dugom roku, prikazan je na Slici 3b. Primetna je kratkoročna asimetrija, gde primat najpre imaju pozitivne, a zatim negativne promene output gepa. Tokom prva tri kvartala, smanjenje output gepa dovodi do povećanja stope inflacije, nakon čega dolazi do njenog smanjenja. Dakle, stopa inflacije značajno reaguje na promene output gepa u kratkom roku, ali je za uspostavljanje dugoročne ravnoteže neophodan znatno duži vremenski period. Prikazani dinamički multiplikatori potvrđuju rezultate Wald testa o prisustvu kratkoročne asimetrije.

Izloženi rezultati empirijske analize se, u kontekstu istraživačkih hipoteza, mogu sumirati na sledeći način. U oba modela novokejnzijanske Filipsove krive, tekuća očekivanja buduće stope inflacije imaju statistički značajan uticaj na stvarnu stopu inflacije, što predstavlja potvrdu prve istraživačke 
Tabela 3 Specifikacija NARDL modela novokejnzijanske Filipsove krive

\begin{tabular}{|c|c|c|c|c|c|}
\hline \multicolumn{3}{|c|}{ Model sa jediničnim troškovima rada } & \multicolumn{3}{|c|}{ Model sa autput gepom } \\
\hline Varijabla & Koeficijent & p-vrednost & Varijabla & Koeficijent & p-vrednost \\
\hline$\alpha_{0}$ & 2,48 & 0,26 & $\alpha_{1}$ & 2,52 & 0,28 \\
\hline$\pi_{(t-1)}$ & $-0,39$ & 0,00 & $\pi_{(t-1)}$ & $-0,64$ & 0,00 \\
\hline$\pi_{(t-1)}^{e}$ & 0,25 & 0,05 & $\pi_{(t-1)}^{e}$ & 0,37 & 0,00 \\
\hline$\varphi_{(t-1)}^{+}$ & 0,11 & 0,06 & $x^{+}(t-1)$ & 0,69 & 0,00 \\
\hline$\varphi_{(t-1)}^{-}$ & 0,23 & 0,00 & $x_{(t-1)}$ & 0,81 & 0,00 \\
\hline$\Delta \pi_{(t-1)}$ & 0,57 & 0,00 & $\Delta \pi_{(t-1)}$ & 0,67 & 0,00 \\
\hline$\Delta \varphi_{t}^{+}$ & $-0,22$ & 0,08 & $\Delta \pi_{(t-2)}$ & 0,51 & 0,00 \\
\hline$\Delta \varphi_{t}$ & 0,07 & 0,62 & $\Delta x_{t}^{+}$ & 0,46 & 0,12 \\
\hline$\Delta \varphi_{(\mathrm{t}-2)}$ & $-0,27$ & 0,02 & $\Delta x_{(t-1)}$ & $-1,23$ & 0,00 \\
\hline D & 4,19 & 0,00 & D & - & - \\
\hline$L_{\varphi}^{+}$ & 0,28 & 0,11 & $L_{x}^{+}$ & 1,09 & 0,00 \\
\hline$L_{\varphi}$ & 0,61 & 0,00 & $L_{x}$ & 1,28 & 0,00 \\
\hline $\mathrm{R}^{2}$ (prilagođen) & \multicolumn{2}{|c|}{0,65} & $\mathrm{R}^{2}$ (prilagođen) & \multicolumn{2}{|c|}{0.68} \\
\hline JB test & 0,80 & 0,67 & JB test & 1,13 & 0,57 \\
\hline BG LM test & 1,17 & 0,32 & BG LM test & 1,44 & 0,25 \\
\hline BPG test & 0,31 & 0,97 & BPG test & 1,98 & 0,08 \\
\hline Cusum test & \multicolumn{2}{|c|}{ Stabilan } & Cusum test & \multicolumn{2}{|c|}{ Stabilan } \\
\hline Cusum Sq. test & \multicolumn{2}{|c|}{ Stabilan } & Cusum Sq. test & \multicolumn{2}{|c|}{ Stabilan } \\
\hline RESET test & 0,74 & 0,39 & RESET test & 0,22 & 0,64 \\
\hline$W_{L R}$ & 11,56 & 0,00 & $W_{L R}$ & 1,29 & 0,26 \\
\hline$W_{S R}$ & 0,01 & 0,95 & $W_{S R}$ & 14,48 & 0,00 \\
\hline $\mathrm{F}_{\mathrm{PSS}}$ & 11,89 & 0,00 & $\mathrm{~F}_{\mathrm{PSS}}$ & 20,06 & 0,00 \\
\hline
\end{tabular}

Napomene: D označava veštačku promenljivu koja predstavlja uticaj strukturnog prekida u vremenskoj seriji; JB, BG LM i BPG predstavljaju Jarque-Bera test normalnosti, Breusch-Godfrey test autokorelacije i Breusch-Pagan-Godfrey test heteroskedastičnosti reziduala, respektivno; Cusum (Cusum Squared) odnosi se na test kumulativne sume reziduala (kvadrata reziduala), čiji je grafički prikaz dat u Prilogu; $W_{L R}$ i $W_{S R}$ označavaju rezultate Wald testa o prisustvu dugoročne i kratkoročne asimetrije, respektivno; $F_{\text {PSS }}$ se odnosi na vrednost F-statistike bounds testa (Pesaran et al, 2001).

Izvor: Autor

hipoteze. Vrednosti koeficijenata očekivane inflacije su relativno niske $(0,25 \mathrm{u}$ prvom i $0,37 \mathrm{u}$ drugom modelu), što znači da ekonomski subjekti u RS većinom formiraju očekivanja inflacije po adaptivnoj šemi, odnosno, na osnovu prošlih stopa inflacije. Ovi rezultati su konzistentni sa nalazima za druge tranzicione privrede i zemlje sa nastajućim tržištem (Dabušinskas \& Kulikov, 2007; Vašiček, 2010; Basarac et al, 2011; Furuoka, 2016).

Empirijska analiza je pokazala da nema dovoljno dokaza da se prihvati druga istraživačka hipoteza. 
Jedinični troškovi rada, kao aproksimacija za realne granične troškove, imaju statistički značajan pozitivan dugoročni uticaj na stopu inflacije u RS, ali samo tokom privredne kontrakcije. Porast ovih troškova u periodu ekspanzije nema statistički značajan efekat na povećanje inflacije. Takođe, njihov dugoročni efekat na stopu inflacije $u$ RS je asimetričan, što je u suprotnosti sa novokejnzijanskom Filipsovom krivom.

Promene output gepa imaju statistički značajan uticaj na stopu inflacije, koja se simetrično prilagođava tokom perioda ekpanzije i kontrakcije privrede RS. Ovaj uticaj je pozitivan, odnosno, stopa inflacije se kreće prociklično (raste tokom ekspanzije, opada tokom kontrakcije privrede). Dakle, treća istraživačka hipoteza se potvrđuje. Budući da u modelu novokejnzijanske Filipsove krive sa output gepom, očekivana buduća inflacija takođe ima statistički značajan uticaj na tekuću stopu, može se zaključiti da je potvrđena validnost ove varijante Filipsove krive $u$ kontekstu privrede RS. Drugim rečima, ova relacija može nosiocima monetarne politike da posluži za praćenje uticaja promena $\mathrm{u}$ realnoj sferi privrede $\mathrm{i}$ inflacionim očekivanjima na dinamiku stvarne stope inflacije.

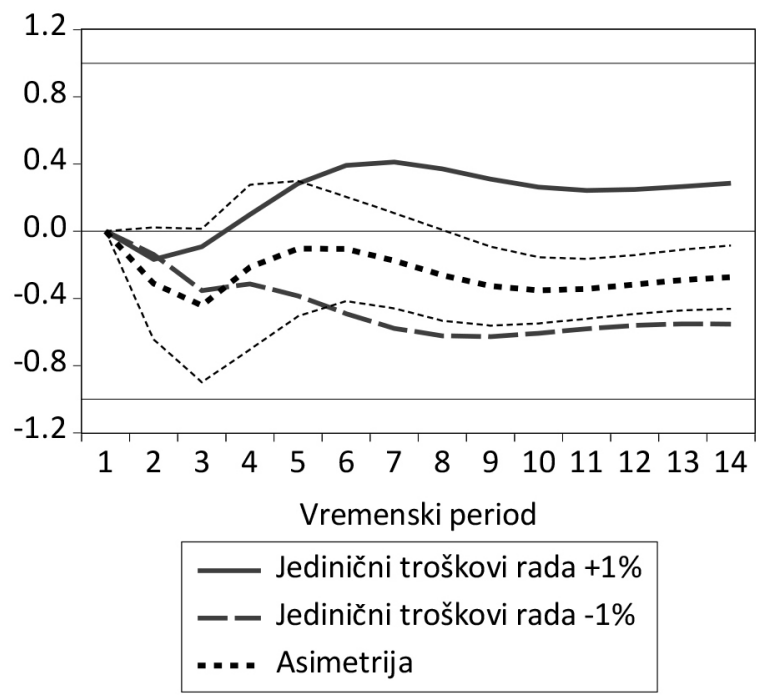

(a)
Vrednost koeficijenta determinacije $\left(\mathrm{R}^{2}\right)$ pokazuje da se promenama $\mathrm{u}$ output gepu i inflacionim očekivanjima može objasniti $68 \%$ varijacija u stopi inflacije u RS u posmatranom periodu. Ovaj nalaz je konzistentan sa rezultatima analize $u$ nedavnoj studiji Svetske banke, $\mathrm{u}$ kojoj se ističe da je oko tri četvrtine promena $\mathrm{u}$ inflaciji rezultat uticaja domaćih pokretača (Ha, Ayhan Kose, Ohnsorge \& Yilmazkuday, 2019). Pored toga, otkrivena razlika u intenzitetu dugoročnog uticaja output gepa na inflaciju u ekspanziji i kontrakciji privrede (koeficijenti $L_{x}^{+} \mathrm{i} L_{x^{\prime}}$; respektivno) implicira da ekspanzivna monetarna politika, koju Narodna banka Srbije sprovodi preko smanjenja referentne kamatne stope može dovesti do intenziviranja privredne aktivnosti bez stvaranja značajnijih inflatornih pritisaka. Ujedno, to je u skladu sa nalazima empirijske studije koju su sproveli P. Petrović, D. Brčerević i M. Gligorić (2017), u kojoj se zaključuje da je privredni rast RS za oko $2 \%$ ispod potencijalnog trenda rasta od $5 \%$ godišnje, odnosno, da je output gep negativan. U tom slučaju, monetarna ekspanzija bi dovela do približavanja stvarnog output-a potencijalnom, bez značajnijeg rasta stope inflacije.

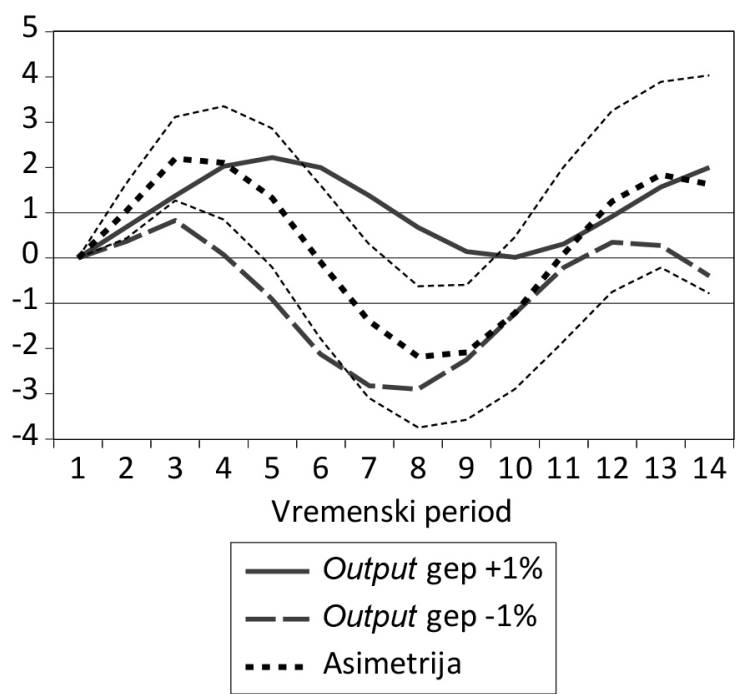

(b)

Slika 3 Dinamički uticaj promena jediničnih troškova rada (a) i output gepa (b) na stopu inflacije 


\section{ZAKLJUČAK}

Istraživanje u ovom radu imalo je za cilj da preispita validnost novokejnzijanske Filipsove krive $u$ kontekstu privrede RS i da empirijski ispita uticaj domaćih pokretača inflacije. Rezultati ocenjenog NARDL modela impliciraju sledeće stavove.

Očekivana buduća inflacija ima statistički značajan uticaj na stvarnu stopu inflacije, bez obzira na specifikaciju novokejnzijanske Filipsove krive, ali je efekat inflacionih očekivanja manje izražen od uticaja prošle inflacije na tekuću stopu.

Realni granični troškovi proizvodnje, aproksimirani jediničnim troškovima rada, ispoljavaju statistički značajan uticaj na stopu inflacije u RS samo tokom perioda privredne kontrakcije. Drugim rečima, efekat ovih troškova na stopu inflacije nije u skladu sa relacijom novokejnzijanske Filipsove krive, budući da je njihov uticaj dugoročno asimetričan, a kratkoročno simetričan. Međutim, identifikovani smer asimetrije sugeriše da se unapređenjem produktivnosti $u$ dugom roku usporava rast troškovne inflacije kao komponente ukupne inflacije.

Promene u vrednosti output gepa tokom perioda ekspanzije i kontrakcije privrede RS imaju pozitivan, statistički značajan i simetričan efekat na stopu inflacije, koji je konzistentan sa ulogom koju output gep ima $\mathrm{u}$ okviru novokejnzijanskog koncepta Filipsove krive. Rezultati empirijske analize ukazuju da inflacija intenzivnije reaguje na negativne nego na pozitivne šokove ponude i tražnje, odnosno, značajnije opada tokom perioda kontrakcije privrede nego što raste tokom faze ekspanzije.

Osnovni doprinos istraživanja je kvantifikacija uticaja domaćih pokretača inflacije u RS (graničnih troškova i output gepa), u različitim fazama privrednog ciklusa i efekata inflacionih očekivanja na bazi ocenjenog ekonometrijskog modela novokejnzijanske Filipsove krive. Analiza mehanizma prilagođavanja stope inflacije na pozitivne i negativne šokove jediničnih troškova rada i output gepa, primenom dinamičkih multiplikatora, unapređuje razumevanje kumulativnog uticaja ekonomskih poremećaja na stopu inflacije od kratkog ka dugom roku.
Ocenjeni model novokejnzijanske Filipsove krive sa output gepom predstavlja argumentaciju u prilog svrsishodnosti ekspanzivne monetarne politike koju Narodna banka Srbije sprovodi tokom posmatranog perioda, budući da se tako može stimulisati privredna aktivnost bez stvaranja značajnijih inflatornih pritisaka.

Empirijska analiza u radu, međutim, nije lišena ograničenja. Najpre, vrednost output gepa dobijena je primenom Hodrik-Preskot filtera, budući da nije podložna direktnoj opservaciji. Primena drugih tehnika dekomponovanja vremenskih serija (kao što su Kalmanov filter, Band-pass filter, itd.), potencijalno bi rezultirala različitim vrednostima output gepa i eventualno vodila drugačijim rezultatima analize. Pored toga, $\mathrm{u}$ istraživanju su korišćeni jedinični troškovi rada, koji se odnose samo na sektor industrije, a ne na celokupnu privredu. Ovi troškovi, takođe, predstavljaju samo aproksimaciju za realne granične troškove, o čijoj stvarnoj dinamici ne postoje raspoloživi podaci. Konačno, iako je istraživanjem obuhvaćen period od 12 godina, broj opservacija je relativno mali (48). Svakako da bi uključivanje u analizu većeg broja opservacija moglo da potpunije osvetli karakter odnosa među posmatranim varijablama.

Buduća istraživanja dinamike inflacije u RS, mogla bi da se baziraju na konceptu tzv. hibridne novokejnzijanske Filipsove krive, koja, pored očekivane buduće inflacije, uključuje i uticaj prošlih stopa inflacije na tekuću stopu. Time bi se egzaktnije kvantifikovao uticaj inercione komponente u dinamici inflacije, što je važno pitanje $\mathrm{u}$ domenu dizajniranja efikasnih mera dezinflacione politike. Takođe, iako domaći pokretači u RS značajno determinišu varijacije $\mathrm{u}$ stopi inflacije, kao i u većini drugih privreda, istraživanje koje bi se baziralo na novokejnzijanskoj Filipsovoj krivoj, proširenoj varijablama otvorene privrede (udeo uvoza/izvoza u BDP-u, cena nafte itd.), moglo bi da identifikuje ključne eksterne činioce stope inflacije, što bi bilo u funkciji unapređenja efikasnosti ekonomske politike usmerene na očuvanje monetarne stabilnosti. 


\section{REFERENCE}

Abdih, Y., Lin. L., \& Paret, A. (2018). Understanding Euro area inflation dynamics: Why so low for so long? IMF Working Paper WP/18/188, Washington.

Alexová, M. (2012). Inflation drivers in new EU members. Working Paper 6/2012, National Bank of Slovakia.

Basarac, M., Škrabić, B., \& Sorić, P. (2011). The hybrid Phillips curve: Empirical evidence from transition economies. Czech Journal of Economics and Finance, 61(4), 367-383.

Bildirici, M. E., \& Sonustun Özaksoy, F. (2018). Backward bending structure of Phillips Curve in Japan, France, Turkey and the U.S.A. Economic Research, 31(1), 537-549. doi: 10.1080/1331677X.2018.1441046

Bouda, M. (2013). Estimation of the New Keynesian Phillips curve in the Czech environment. Acta Oeconomica Pragensia, 5, 31-46. doi:10.18267/j.aop.414

Chin, K. H. (2018). New Keynesian Phillips curve with timevarying parameters. Empirical Economics, 57(6), 1869-1889. doi:10.1007/s00181-018-1536-2

Dabušinskas, A., \& Kulikov, D. (2007). New Keynesian Phillips curve for Estonia, Latvia and Lithuania. Working Paper 7/2007, Eesti Pank, Bank of Estonia.

Egan, P. G., \& Leddin, A. J. (2017). The Chinese Phillips curve - Inflation dynamics in the presence of structural change. Journal of Chinese Economic and Business Studies, 15(2), 165184. doi:10.1080/14765284.2017.1325597

European Central Bank. (2017). ECB Economic Bulletin, 4/2017.

Friedrich, C. (2016). Global inflation dynamics in the postcrisis period: What explains the puzzles? Economics Letters, 142(C), 31-34. doi:10.1016/j.econlet.2016.02.032

Furuoka, F. (2016). A scientific inquiry on the estimation of the Phillips curve in the Baltic region. Engineering Economics, 27(3), 276-284. doi:10.5755/j01.ee.27.3.6896

Galí, J., \& Gertler, M. (1999). Inflation dynamics: A structural econometric analysis. Journal of Monetary Economics, 44(2), 195-222. doi:10.1016/S0304-3932(99)00023-9

Galí, J. (2008). Monetary Policy, Inflation, and the Business Cycle: An Introduction to the New Keynesian Framework. New Jersey, NJ: Princeton University Press.
Globan, T., Arčabić, V., \& Sorić, P. (2015). Inflation in new EU member states: A domestically or externally driven phenomenon? Emerging Markets Finance and Trade 51(6), 1-15.

Ha, J., Ayhan Kose, M., Ohnsorge, F., \& Yilmazkuday, H. (2019). Sources of inflation: Global and domestic drivers. In J. Ha, M. Ayhan Kose, \& F. Ohnsorge (Eds.). Inflation in Emerging and Developing Economies: Evolution, Drivers, and Policies (pp. 143-199). Washington DC: International Bank for Reconstruction and Development/The World Bank.

Hałka, A., \& Kotłowski, J. (2016). Global or domestic? Which shocks drive inflation in European small open economies? Emerging Markets Finance and Trade, 53(8), 1812-1835. doi:10.1 080/1540496X.2016.1193001

Hatemi-J, A. (2012). Asymmetric causality tests with an application. Empirical economics, 43(1), 447-456. doi:10.1007/ s00181-011-0484-x

Ho, S., \& Iyke, B. N. (2019). Unemployment and inflation: Evidence of a nonlinear Phillips curve in the Eurozone. The Journal of Developing Areas, 53(4), 151-163. doi:10.1353/ jda.2018.0077

Jarociński, M., \& Lenza, M. (2018). An inflation-predicting measure of the output gap in the Euro area. Journal of Money, Credit and Banking, 50(6), 1189-1224. doi:10.1111/jmcb.12496

Jašová, M., Moessner, R., \& Takáts, E. (2018). Domestic and global output gaps as inflation drivers: What does the Phillips curve tell? BIS Working Papers, No. 748, Bank for International Settlements, Switzerland.

Lagoa, S. (2014). Determinants of inflation differentials in the Euro area: Is the New Keynesian Phillips curve enough? Journal of Applied Economics, 20(1), 75-103. doi:10.1016/S15140326(17)30004-1

Lepetit, A. (2018). Asymmetric unemployment fluctuations and monetary policy trade-offs. HAL Working Paper 01536416 .

Mazumder, S. (2012). European inflation and the New Keynesian Phillips curve. Southern Economic Journal, 79(2), 322-349. doi:10.4284/0038-4038-2011.149

Moosa, I. A., 1997. A cross-country comparison of Okun's coefficient. Journal of Comparative Economics, 24(3), 335-356.

Morley, J., \& Panovska, I. B. (2019). Is business cycle asymmetry intrinsic in industrialized economies? Macroeconomic Dynamics, 1-34. doi:10.1017/S1365100518000913 
Narodna banka Srbije (2018). Godišnji izveštaj o monetarnoj politici u 2018. godini. Beograd, RS: Narodna banka Srbije.

Oinonen, S., \& Paloviita, M. (2014). Updating the Euro area Phillips curve: The slope has increased. Research Discussion Paper No. 31/2014, Bank of Finland.

Orphanides, A., \& van Norden, S. (2005). The reliability of inflation forecasts based on output gap estimates in real time. Journal of Money, Credit and Banking, 37(3), 583-601.

Peneva, E. V., \& Rudd, J. B. (2017). The passthrough of labor costs to price inflation. Journal of Money, Credit and Banking, 49(8), 1777-1802. doi:10.1111/jmcb.12449

Pesaran, M. H., Shin, Y., \& Smith, R. J. (2001). Bounds testing approaches to the analysis of level relationships. Journal of Applied Econometrics, 16(3), 289-326. doi:10.1002/jae.616

Petrović, P., Mladenović, Z., \& Nojković, A. (2011). Inflation triggers in transition economies: Their evolution and specific features. Emerging Markets Finance and Trade, 47(5), 101-124. doi:10.2753/REE1540-496X470505

Petrović, P., Brčerević D., \& Gligorić M. (2019). Why is Serbia an economic growth underachiever? Ekonomika preduzeća, 67(1-2), 17-32. doi:10.5937/ekopre1808017P

Posch, J., \& Rumler, F. (2014). Semi-structural forecasting of UK inflation based on the hybrid New Keynesian Phillips curve. Journal of Forecasting, 34(2), 145-162. doi:10.1002/ for.2319
Shin, Y., Yu, B., \& Greenwood-Nimmo, M. (2014). Modelling asymmetric cointegration and dynamic multipliers in anonlinear ARDL framework. In R. Sickles, \& W. Horrace (Eds.). Festschrift in honor of Peter Schmidt (pp. 281-314). Germany: Springer.

Toda, H. Y., \& Yamamoto, T. (1995). Statistical inference in vector autoregressions with possibly integrated processes. Journal of Econometrics, 66(1-2), 225-250. doi:10.1016/03044076(94)01616-8

Vašíček, B. (2011). Inflation dynamics and the New Keynesian Phillips curve in four Central European countries. Emerging Markets Finance and Trade, 47(5), 71-100. doi:10.2753/REE1540496X470504

Vasilev, A. (2015). New Keynesian Phillips curve estimation: The case of Hungary (1981-2006). Managing Global Transitions, 13(4), 355-367.

Wolde-Rufael, Y. (2005). Energy demand and economic growth: The African experience. Journal of Policy Modeling, 27(8), 891-903. doi:10.1016/j.jpolmod.2005.06.003

Xu, Q., Niu, X., Jiang, C., \& Huang, X. (2015). The Phillips curve in the US: A nonlinear quantile regression approach. Economic Modelling, 49(C), 186-197. doi:10.1016/j. econmod.2015.04.007

Zivot, E., \& Andrews, D. W. K. (1992). Further evidence on the great crash, the oil-price shock, and the unit-root hypothesis. Journal of Business \& Economic Statistics, 10(3), 251-270. doi:10.2307/1391541

Primljeno 6. aprila 2020, nakon revizije, prihvaćeno za publikovanje 17. avgusta 2020. Elektronska verzija objavljena 19. avgusta 2020.

Vladimir Mihajlović je docent na Ekonomskom fakultetu Univerziteta u Kragujevcu, gde je doktorirao u naučnoj oblasti Opšta ekonomija i privredni razvoj. Glavne oblasti njegovog naučnog istraživanja odnose se na razvoj ekonomske misli, makroekonomsku analizu i modeliranje, i tržište rada. 


\section{PRILOG}

Grafički prikazi rezultata testova dinamičke stabilnosti modela novokejnzijanske Filipsove krive
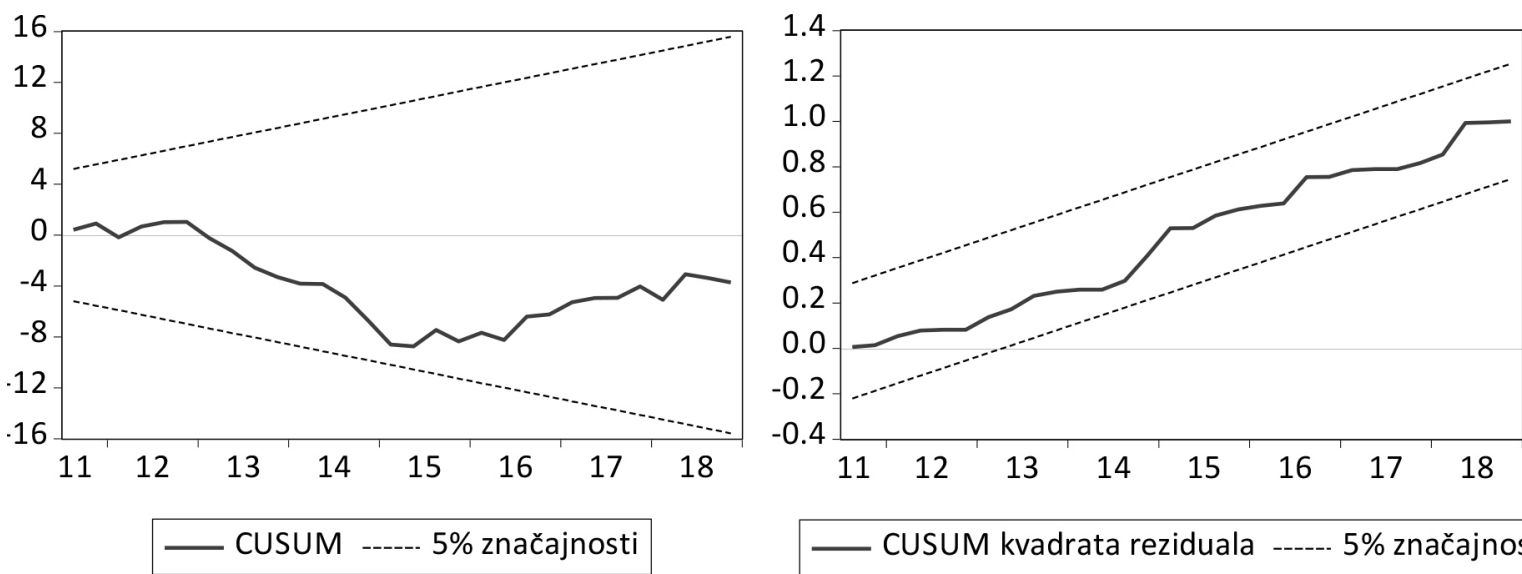

CUSUM kvadrata reziduala $5 \%$ značajnosti

Model sa jediničnim troškovima rada
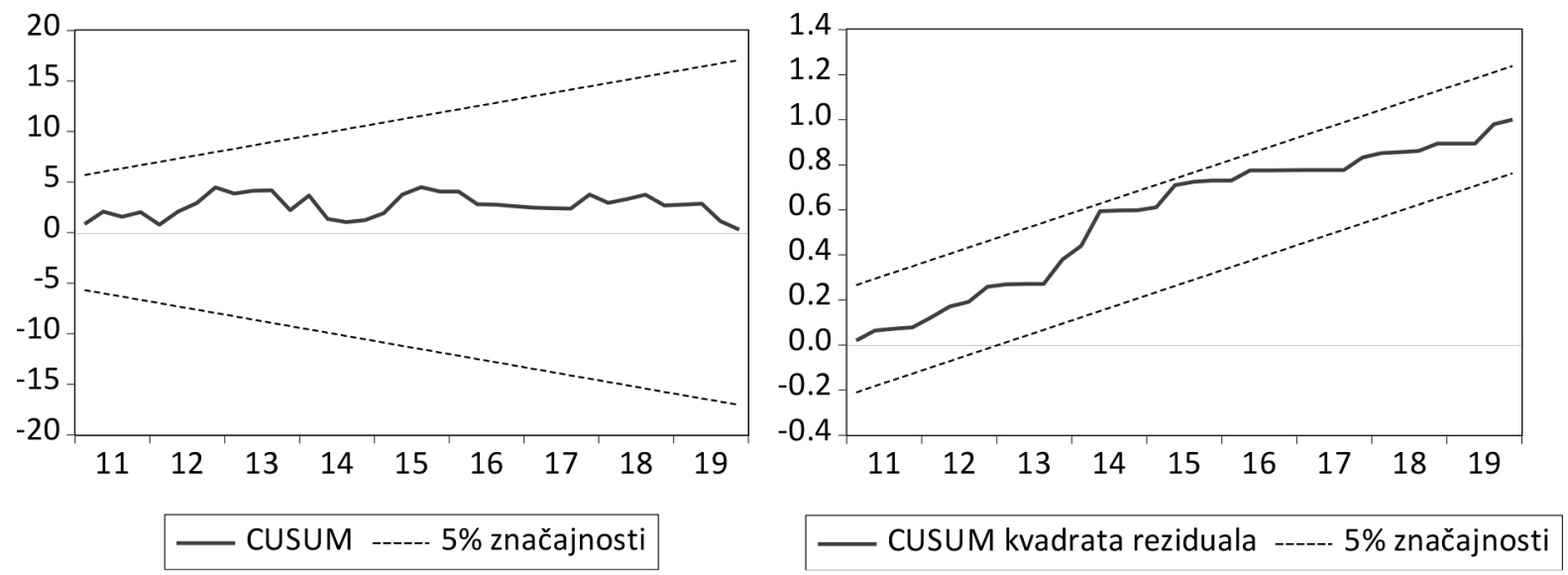

Model sa output gepom

Izvor: Autor 


\title{
THE NEW KEYNESIAN PHILLIPS CURVE AND THE EFFECTS OF DOMESTIC INFLATION DRIVERS IN THE REPUBLIC OF SERBIA
}

\author{
Vladimir Mihajlovic \\ Faculty of Economics, University of Kragujevac, Kragujevac, The Republic of Serbia
}

This study investigates the validity of the New Keynesian Phillips curve in the Republic of Serbia. By means of empirical analysis, the impact of domestic inflation drivers, i.e. inflation expectations, real marginal costs and the output gap, is quantified. The results reveal that inflation in Serbia responds more intensively to negative rather than positive supply and demand shocks as it decreases more significantly in economic contraction than in expansion. The estimated model of the New Keynesian Phillips curve with marginal costs gives the unambiguous evidence that the growth of cost-push inflation could be reduced by a productivity-enhancing policy. Expected inflation significantly impacts the actual inflation rate, albeit inflation dynamics are dominated by inertia, i.e. past rates affect the current. The empirical estimate of the New Keynesian Phillips curve model with the output gap that indicates monetary expansion in the Republic of Serbia might, inter alia, stimulate the economic activity without causing significant inflationary pressures to occur.

Keywords: inflation rate, output gap, unit labor costs, nonlinear ARDL model, dynamic multiplier, asymmetry

JEL Classification: B22, C13, C32, E31 